\title{
Changes in soil carbon, nitrogen, and phosphorus due to land-use changes in Brazil
}

\author{
J. D. Groppo ${ }^{1}$, S. R. M. Lins ${ }^{5}$, P. B. Camargo ${ }^{5}$, E. D. Assad $^{1}$, H. S. Pinto ${ }^{2}$, S. C. Martins $^{6}$, P. R. Salgado ${ }^{3}$, \\ B. Evangelista ${ }^{4}$, E. Vasconcellos ${ }^{1}$, E. E. Sano ${ }^{4}$, E. Pavão ${ }^{1}$, R. Luna ${ }^{1}$, and L. A. Martinelli ${ }^{5}$ \\ ${ }^{1}$ Brazilian Agricultural Research Corporation, EMBRAPA Agricultural Informatics, Campinas, São Paulo State, Brazil \\ ${ }^{2}$ University of Campinas - UNICAMP, Campinas, São Paulo State, Brazil \\ ${ }^{3}$ Brazilian Agricultural Research Corporation, EMBRAPA Coffee, Brasilia, DF, Brazil \\ ${ }^{4}$ Brazilian Agricultural Research Corporation, EMBRAPA Agropecuária do Cerrado, Brasilia, DF, Brazil \\ ${ }^{5}$ University of São Paulo - USP, Centro de Energia Nuclear na Agricultura, Piracicaba, São Paulo State, Brazil \\ ${ }^{6}$ Fundação Getúlio Vargas, São Paulo, São Paulo State, Brazil \\ Correspondence to: J. D. Groppo (jdgroppo@gmail.com)
}

Received: 3 November 2014 - Published in Biogeosciences Discuss.: 4 February 2015

Revised: 23 July 2015 - Accepted: 24 July 2015 - Published: 7 August 2015

\begin{abstract}
In this paper, soil carbon, nitrogen and phosphorus concentrations and stocks were investigated in agricultural and natural areas in 17 plot-level paired sites and in a regional survey encompassing more than 100 pasture soils In the paired sites, elemental soil concentrations and stocks were determined in native vegetation (forests and savannas), pastures and crop-livestock systems (CPSs). Nutrient stocks were calculated for the soil depth intervals $0-10,0-30$, and $0-60 \mathrm{~cm}$ for the paired sites and $0-10$, and $0-30 \mathrm{~cm}$ for the pasture regional survey by sum stocks obtained in each sampling intervals $(0-5,5-10,10-20,20-30,30-40,40-60 \mathrm{~cm})$. Overall, there were significant differences in soil element concentrations and ratios between different land uses, especially in the surface soil layers. Carbon and nitrogen contents were lower, while phosphorus contents were higher in the pasture and CPS soils than in native vegetation soils. Additionally, soil stoichiometry has changed with changes in land use. The soil $\mathrm{C}: \mathrm{N}$ ratio was lower in the native vegetation than in the pasture and CPS soils, and the carbon and nitrogen to available phosphorus ratio $\left(\mathrm{P}_{\mathrm{ME}}\right)$ decreased from the native vegetation to the pasture to the CPS soils. In the plotlevel paired sites, the soil nitrogen stocks were lower in all depth intervals in pasture and in the CPS soils when compared with the native vegetation soils. On the other hand, the soil phosphorus stocks were higher in all depth intervals in agricultural soils when compared with the native vegetation soils. For the regional pasture survey, soil nitrogen and phos-
\end{abstract}

phorus stocks were lower in all soil intervals in pasture soils than in native vegetation soils. The nitrogen loss with cultivation observed here is in line with other studies and it seems to be a combination of decreasing organic matter inputs, in cases where crops replaced native forests, with an increase in soil organic matter decomposition that leads to a decrease in the long run. The main cause of the increase in soil phosphorus stocks in the CPS and pastures of the plot-level paired site seems to be linked to phosphorus fertilization by mineral and organics fertilizers. The findings of this paper illustrate that land-use changes that are currently common in Brazil alter soil concentrations, stocks and elemental ratios of carbon, nitrogen and phosphorus. These changes could have an impact on the subsequent vegetation, decreasing soil carbon and increasing nitrogen limitation but alleviating soil phosphorus deficiency.

\section{Introduction}

The demand for food will continue to grow in order to feed a population that will reach near 9 billion people worldwide in 2050 (Tilman et al., 2011). Brazil is one of the pivotal countries that will have a key role in the global food production system (Martinelli et al., 2010). There is already a consensus that an increase in food production cannot be achieved by replacing native vegetation with agricultural fields (Tilman et 
al., 2011). One of the alternatives that has been proposed is agricultural intensification, which means not only an increase in productivity but also an attempt to increase sustainability (Godfray et al., 2010). Sustainable agriculture (SA) has been proposed as one way to achieve both goals. SA tries to mimic natural ecosystems by adding layers of complexity in an attempt to depart from simplistic monoculture fields (Keating et al., 2010).

Crop-livestock systems (CPSs) are a suitable example of this attempt to add a layer of complexity to agricultural fields. Integrated crop-livestock or crop-livestock-forest, and agroforestry systems are not a new idea. However, these systems have only been consolidated in recent decades (Machado et al., 2011). The system consists of diversifying and integrating crop, livestock and forestry systems, within the same area, in intercropping, in succession or rotation. The system can provide environmental benefits such as soil conservation, building up soil carbon, reducing environmental externalities and ultimately increasing productivity. CPSs include but are not restricted to the following: no-till, the use of cover crops, elimination of agricultural fires (slash and burn), and restoration of vast areas of degraded pastures (Machado et al., 2011; Bustamante et al., 2012; Lapola et al., 2014). Additionally, the Brazilian law (Law no. 12187 of 29 December 2009) encourages the adoption of good agricultural practices to promote low carbon emission (Low Carbon Emission Program ABC Program) and stipulates that mitigation should be conducted by adopting (i) recovery of degraded pastures, (ii) a no-tillage system, (iii) integrated livestock-crop-forest systems, and (iv) re-forestation in order to reduce approximately 35 to $40 \%$ of Brazil's projected greenhouse gas emissions by 2020 (Assad et al., 2013).

The CPSs have been evaluated in several ways, especially regarding soil carbon balance with cultivation (Sá et al., 2001; Ogle et al., 2005; Zinn et al., 2005; Bayer et al., 2006; Baker et al., 2007). On the other hand, there are few regional studies considering how nitrogen and phosphorus soil contents will be affected in these integrated agricultural systems. Plot-level studies have reported a decrease in soil nitrogen stocks with cultivation in several $\mathrm{N}$-fertilized areas of Brazil and under different cropping systems (Lima et al., 2011; Fracetto et al., 2012; Barros et al., 2013; Sacramento et al., 2013; Cardoso et al., 2010; Silva et al., 2011; Guareschi et al., 2012; Sisti et al., 2004; Santana et al., 2013; Sá et al., 2013). The same trend has been observed in Chernozem soils in Russia and in prairie soils of Wisconsin in the USA (Mikhailova et al., 2000; Kucharik et al., 2001). In unfertilized pasture soils of Brazil, nitrogen availability decreased as the age of pastures increased. In theses soils, there was an inversion in relation to forest soils, and an ammonium dominance over nitrate was observed, followed by lower mineralization and nitrification rates that in turn were followed by lower emissions of $\mathrm{N}_{2} \mathrm{O}$ (Davidson et al., 2000; Erickson et al., 2001; Wick et al., 2005; Neill et al., 2005; Cerri et al., 2006; Carmo et al., 2012). Therefore, it seems that, receiving
$\mathrm{N}$-fertilizer inputs or not, agro-ecosystem nitrogen losses via leaching, gaseous forms, and harvesting exports are higher than $\mathrm{N}$ inputs, resulting in decreased soil nitrogen stocks.

Phosphorus is particularly important in the tropics due to phosphorus adsorption on oxides and clay minerals rendering it unavailable to plants (Uehara and Gillman, 1981; Sanchez et al., 1982; Oberson et al., 2001; Numata et al., 2007; GamaRodriguez et al., 2014). This $\mathrm{P}$ adsorption, as well as the fact that phosphorus does not have a gaseous phase like nitrogen, renders phosphorus less mobile in the soil-plant-atmosphere system than nitrogen (Walker and Syers, 1976). One consequence of this lower phosphorus mobility throughout the soil profile is that when $\mathrm{P}$ fertilizers are applied, they tend to increase soil phosphorus concentration on the soil surface, but they also make phosphorus available by loss through the soil erosion process and surface runoff (Messiga et al., 2013). The use of agricultural practices like no-till may further increases phosphorus concentration in the surface soil due to the non-movement of the soil layer (Pavinatto et al., 2009; Messiga et al., 2010, 2013). Soil phosphorus is also affected by physical characteristics of the soil, such as how the size of soil aggregates influences the extent of soil phosphorus availability to plants (Fonte et al., 2014). Therefore, agricultural practices have the potential to alter soil phosphorus concentration and consequently soil phosphorus stocks (Tiessen et al., 1982; Tiessen and Stewart, 1983; Ball-Coelho et al., 1993; Aguiar et al., 2013).

Besides concentrations and stocks, agricultural management is also capable of altering the ratios between carbon, nitrogen and phosphorus (C: N : P; Tiessen et al., 1982; Tiessen and Stewart, 1983; Ding et al., 2013; Jiao et al., 2013; Schrumpf et al., 2014; Tischer et al., 2014). For instance, soil microorganisms adjusting their stoichiometry with that of the substrate may release or immobilize nitrogen depending on the substrate $\mathrm{C}: \mathrm{N}$ ratio (Walker and Adams, 1958; Mooshammer et al., 2014a). In turn, litter decomposition also depends on the stoichiometry of the litter, especially on the $\mathrm{C}: \mathrm{N}$ ratios (Hättenschwiler et al., 2011). These adjustments guided by $\mathrm{C}: \mathrm{N}: \mathrm{P}$ ratios may ultimately interfere in crop production, which in turn will affect soil carbon sequestration and, consequently, agro-ecosystem responses to climate change (Hessen et al., 2004; Cleveland and Liptzin, 2007; Allison et al., 2010).

Agricultural land in Brazil has increased dramatically over recent decades and part of this increase contributed to increase deforestation rates in all major Brazilian biomes (Lapola et al., 2014). Particularly important in Brazilian agriculture is the area covered with pasture that includes approximately 200 million hectares encompassing degraded areas with well-managed pasture (Martinelli et al., 2010). Arable land comprises almost 70 million hectares, with approximately 30 million hectares under no-till cultivation (Boddey et al., 2010), with CPSs being especially important in the southern region of the country. 
Most studies in Brazil on the effects of agricultural practices on soil properties deal with soil carbon stocks due to its importance for a low-carbon agriculture (Sá et al., 2001; Bayer et al., 2006; Marchão et al., 2009; Maia et al., 2009; Braz et al., 2012; Assad et al., 2013; Mello et al., 2014). On the other hand, there are fewer studies on agricultural practices affecting soil nitrogen concentration, and especially stocks, and even fewer studies on changes in soil phosphorus stocks. Based on this, this paper aims to investigate effects of agricultural practices on carbon, nitrogen and phosphorus soil concentration and stocks, plus the soil stoichiometry $(\mathrm{C}: \mathrm{N}: \mathrm{P}$ ratio), in several Brazilian regions using the same study sites and methodology used by Assad et al. (2013), who evaluated changes in soil carbon stocks due to different land uses. Two sampling approaches were used in Assad et al. (2013): the first, at the plot level, addressed 17 paired sites, comparing soil stocks among native vegetation, pasture and CPSs, and the second was a regional survey of pasture soils in more than 100 sites.

\section{Material and methods}

\subsection{Study area}

A full description of the study area can be found in Assad et al. (2013). Briefly, we conducted two types of surveys: one at the regional level, exclusively in pasture soils, and another in which 17 plot-level paired sites were sampled encompassing soils of pastures, CPSs and native vegetation. The regional pasture survey was conducted in November and December of 2010, and 115 pastures located between 6.58 and $31.53^{\circ} \mathrm{S}$ were selected based first on satellite images in an attempt to broadly encompass three major Brazilian biomes: Cerrado, Atlantic Forest and Pampa, and, secondly, sites were also selected based on their ability to be accessed by roads (Fig. 1). A bias in this scheme is that sampling sites were not randomly selected. A second bias is that, although all pastures were in use at the time they were sampled, it was difficult to visually assess their grazing conditions or stocking rates, which may affect the soil nutrient stocks (Maia et al., 2009; Braz et al., 2012; Assad et al., 2013).

Paired sites were selected by the EMBRAPA (Empresa Brasileira de Pesquisa Agropecuária) regional offices and sampled between November and December 2011. At these sites, there was an attempt to sample areas of native vegetation, pasture and sites that encompass crop rotation integrated with livestock (CPSs). A detailed description of crop rotation and sites that combine crops and livestock management is shown in Table 1. Native vegetation is composed of wood vegetation in the Atlantic Forest or Cerrado biome characteristics. In sites located in the southern region of the country (Arroio dos Ratos, Tuparecetã, Bagé, and Capão do Leão), the original vegetation is grassy temperate savanna locally referred to as Campos, which belongs

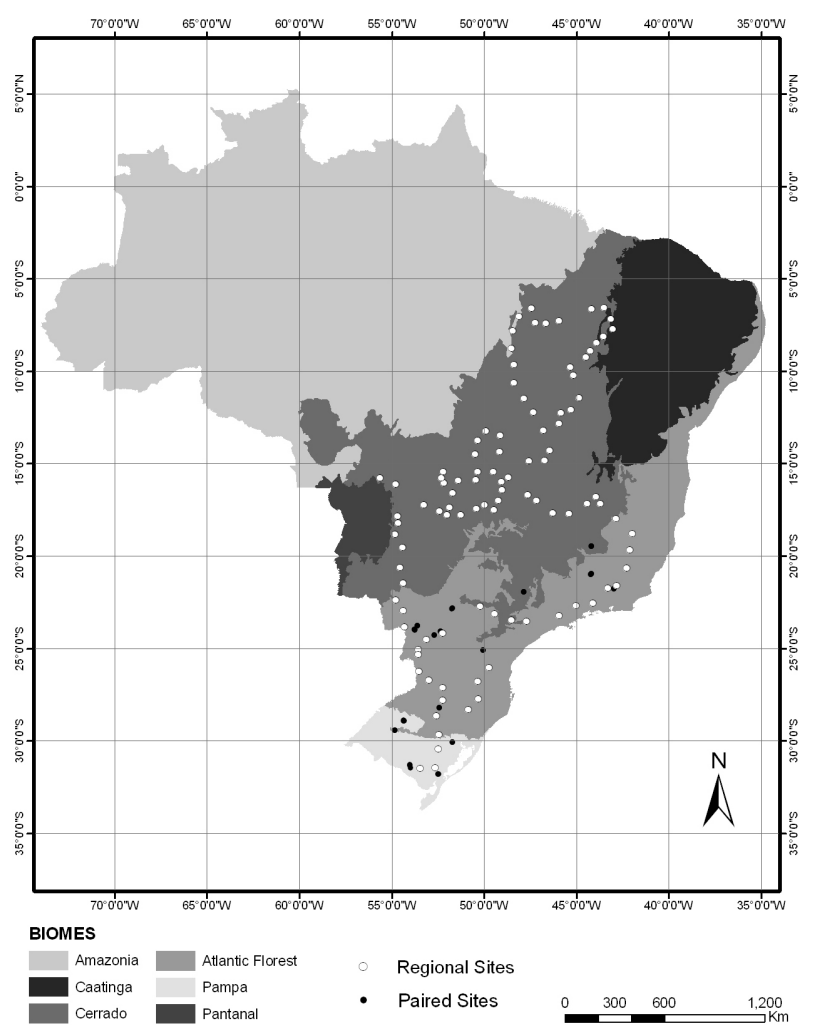

Figure 1. Sampling sites located throughout Brazil. White circles indicate pasture sites of the regional survey; black circles indicate paired study sites, and various shaded areas indicate Brazilian biomes.

to the Pampa biome (Table 1). For the sake of simplicity, forests and Campos soils were grouped under the category named "native vegetation". Pasture was composed mostly of $\mathrm{C}_{4}$ grass species of the genus Urochloa (ex Brachiaria); exceptions were in sites located in the southern region of the country where a $\mathrm{C}_{3}$ grass (Lolium perenne) was cultivated. In Brazil, land-use history is always difficult to obtain with accuracy, but Assad et al. (2013), using $\delta^{13} \mathrm{C}$ values of soil organic matter, showed that most pastures have been in this condition for a long time, and most of the native vegetation seems to have been in this state also for a long time. The precipitation and temperatures were obtained using the Prediction of Worldwide Energy Resource (POWER) project (http://power.larc.nasa.gov).

\subsection{Sample collection and analysis}

Soil sampling is described in detail in Assad et al. (2013). Briefly, in each site, a trench of 60 by $60 \mathrm{~cm}$, yielding an area of approximately $360 \mathrm{~cm}^{2}$, was excavated. For the regional pasture survey, the depth of the trench was approximately $30 \mathrm{~cm}$, and in the paired sites, the depth was approximately $60 \mathrm{~cm}$. Trenches were excavated according to interval depth samples for bulk density were collected first, and after this 
Table 1. Characterization of sampled sites: native vegetation (NV), pastures $(P)$, crop-livestock systems (CPS).

\begin{tabular}{|c|c|c|c|c|c|c|}
\hline City (code) - region & Point & Latitude & Longitude & Land-use system & Established & Biome \\
\hline \multirow{5}{*}{$\begin{array}{l}\text { Sete Lagoas (SL) - } \\
\text { southeast }\end{array}$} & 1 & $19^{\circ} 29^{\prime} 57^{\prime \prime}$ & $44^{\circ} 11^{\prime} 03^{\prime \prime}$ & Pasture & - & Cerrado \\
\hline & 2 & $19^{\circ} 29^{\prime} 24^{\prime \prime}$ & $44^{\circ} 10^{\prime} 48^{\prime \prime}$ & $\begin{array}{r}\text { CPS ( } 1 \text { year of pasture } \\
\text { followed by } 2 \text { years of corn })\end{array}$ & - & Cerrado \\
\hline & 3 & $19^{\circ} 29^{\prime} 11^{\prime \prime}$ & $44^{\circ} 11^{\prime} 19^{\prime \prime}$ & $\begin{array}{r}\text { CPS (corn, } \\
\text { pasture and eucalyptus) }\end{array}$ & 2009 & Cerrado \\
\hline & 4 & $19^{\circ} 29^{\prime} 37^{\prime \prime}$ & $44^{\circ} 11^{\prime} 09^{\prime \prime}$ & Forest & - & Cerrado \\
\hline & 5 & $19^{\circ} 29^{\prime} 28^{\prime \prime}$ & $44^{\circ} 11^{\prime} 08^{\prime \prime}$ & $\begin{array}{r}\text { CPS (1 year of pasture } \\
\text { followed by } 2 \text { years of soybean) }\end{array}$ & - & Cerrado \\
\hline \multirow{6}{*}{$\begin{array}{l}\text { Coronel Xavier }(\mathrm{CX})- \\
\text { southeast }\end{array}$} & 6 & $21^{\circ} 01^{\prime} 06^{\prime \prime}$ & $44^{\circ} 12^{\prime} 53^{\prime \prime}$ & Native vegetation & - & Atlantic Forest \\
\hline & 7 & $21^{\circ} 01^{\prime} 13^{\prime \prime}$ & $44^{\circ} 12^{\prime} 56^{\prime \prime}$ & Pasture & - & Atlantic Forest \\
\hline & 8 & $21^{\circ} 01^{\prime} 12^{\prime \prime}$ & $44^{\circ} 12^{\prime} 53^{\prime \prime}$ & $\begin{array}{r}\text { CPS (corn, pasture } \\
\text { and eucalyptus) }\end{array}$ & 2009 & Atlantic Forest \\
\hline & 9 & $20^{\circ} 59^{\prime} 35^{\prime}$ & $44^{\circ} 10^{\prime} 18^{\prime \prime}$ & Pasture & - & Atlantic Forest \\
\hline & 10 & $20^{\circ} 59^{\prime} 36^{\prime \prime}$ & $44^{\circ} 10^{\prime} 18^{\prime \prime}$ & Forest & - & Atlantic Forest \\
\hline & 11 & $20^{\circ} 59^{\prime} 40^{\prime \prime}$ & $44^{\circ} 10^{\prime} 20^{\prime \prime}$ & $\begin{array}{r}\text { CPS (corn, pasture } \\
\text { and eucalyptus) }\end{array}$ & 2009 & Atlantic Forest \\
\hline \multirow{4}{*}{$\begin{array}{l}\text { São Carlos (SC) - } \\
\text { southeast }\end{array}$} & 15 & $21^{\circ} 58^{\prime} 49^{\prime \prime}$ & $47^{\circ} 51^{\prime} 10^{\prime \prime}$ & Pasture & - & Cerrado \\
\hline & 16 & $21^{\circ} 58^{\prime} 27^{\prime \prime}$ & $47^{\circ} 51^{\prime} 10^{\prime \prime}$ & $\begin{array}{r}\text { CPS (pasture } \\
\text { and eucalyptus) }\end{array}$ & 2010 & Cerrado \\
\hline & 17 & $21^{\circ} 58^{\prime} 38^{\prime \prime}$ & $47^{\circ} 51^{\prime} 17^{\prime \prime}$ & Forest & - & Cerrado \\
\hline & 18 & $21^{\circ} 57^{\prime} 47^{\prime \prime}$ & $47^{\circ} 51^{\prime} 00^{\prime \prime}$ & $\begin{array}{r}\text { CPS (pasture } \\
\text { and eucalyptus) }\end{array}$ & 2007 & Cerrado \\
\hline \multirow[t]{3}{*}{$\begin{array}{l}\text { Cafeara }(\mathrm{CS})- \\
\text { southeast }\end{array}$} & 19 & $22^{\circ} 50^{\prime} 38^{\prime \prime}$ & $51^{\circ} 42^{\prime} 28^{\prime \prime}$ & $\begin{array}{l}\text { CPS (pasture } \\
\text { and soybean) }\end{array}$ & 2003 & Atlantic Forest \\
\hline & 20 & $22^{\circ} 50^{\prime} 02^{\prime \prime}$ & $51^{\circ} 42^{\prime} 52^{\prime \prime}$ & Forest & - & Atlantic Forest \\
\hline & 21 & $22^{\circ} 52^{\prime} 12^{\prime \prime}$ & $51^{\circ} 43^{\prime} 37^{\prime \prime}$ & Pasture & - & Atlantic Forest \\
\hline \multirow[t]{3}{*}{$\begin{array}{l}\text { Iporã (IP) - } \\
\text { southeast }\end{array}$} & 22 & $24^{\circ} 00^{\prime} 26^{\prime \prime}$ & $53^{\circ} 45^{\prime} 01^{\prime \prime}$ & $\begin{array}{l}\text { CPS ( } 1 \text { year of pasture } \\
\text { and } 3 \text { years of soybean) }\end{array}$ & - & Atlantic Forest \\
\hline & 23 & $24^{\circ} 00^{\prime} 06^{\prime \prime}$ & $53^{\circ} 45^{\prime} 32^{\prime \prime}$ & Pasture & - & Atlantic Forest \\
\hline & 24 & $24^{\circ} 01^{\prime} 20^{\prime \prime}$ & $53^{\circ} 45^{\prime} 38^{\prime \prime}$ & Forest & - & Atlantic Forest \\
\hline \multirow{4}{*}{$\begin{array}{l}\text { Xambrê }(\mathrm{XA})- \\
\text { southeast }\end{array}$} & 25 & $23^{\circ} 47^{\prime} 34^{\prime \prime}$ & $53^{\circ} 36^{\prime} 20^{\prime \prime}$ & Pasture & - & Atlantic Forest \\
\hline & 26 & $23^{\circ} 47^{\prime} 14^{\prime \prime}$ & $53^{\circ} 36^{\prime} 10^{\prime \prime}$ & $\begin{array}{l}\text { CPS (pasture } \\
\text { and soybean) }\end{array}$ & 2000 & Atlantic Forest \\
\hline & 27 & $23^{\circ} 47^{\prime} 23^{\prime \prime}$ & $53^{\circ} 36^{\prime} 31^{\prime \prime}$ & $\begin{array}{r}\text { CPS (soybean } \\
\text { and eucalyptus) }\end{array}$ & 2010 & Atlantic Forest \\
\hline & 28 & $23^{\circ} 48^{\prime} 29^{\prime \prime}$ & $53^{\circ} 35^{\prime} 25^{\prime \prime}$ & Forest & - & Atlantic Forest \\
\hline \multirow{3}{*}{$\begin{array}{l}\text { Campo Mourão }(\mathrm{CM})- \\
\text { southeast }\end{array}$} & 29 & $24^{\circ} 06^{\prime} 25^{\prime \prime}$ & $52^{\circ} 21^{\prime} 40^{\prime \prime}$ & Pasture & - & Atlantic Forest \\
\hline & 30 & $24^{\circ} 06^{\prime} 21^{\prime \prime}$ & $52^{\circ} 21^{\prime} 34^{\prime \prime}$ & CPS (corn and pasture) & 2001 & Atlantic Forest \\
\hline & 31 & $24^{\circ} 06^{\prime} 18^{\prime \prime}$ & $52^{\circ} 21^{\prime} 34^{\prime \prime}$ & Forest & - & Atlantic Forest \\
\hline \multirow[t]{3}{*}{$\begin{array}{l}\text { Juranda }(\mathrm{JU})- \\
\text { southeast }\end{array}$} & 32 & $24^{\circ} 18^{\prime} 21^{\prime \prime}$ & $52^{\circ} 42^{\prime} 17^{\prime \prime}$ & $\begin{array}{r}\text { CPS (rotation soybean } \\
\text { or corn and pasture) }\end{array}$ & 2006 & Atlantic Forest \\
\hline & 33 & $24^{\circ} 18^{\prime} 34^{\prime \prime}$ & $52^{\circ} 42^{\prime} 16^{\prime \prime}$ & Pasture & - & Atlantic Forest \\
\hline & 34 & $24^{\circ} 18^{\prime} 10^{\prime \prime}$ & $52^{\circ} 42^{\prime} 18^{\prime \prime}$ & Forest & - & Atlantic Forest \\
\hline \multirow[t]{4}{*}{$\begin{array}{l}\text { Ponta Grossa (PG) - } \\
\text { southeast }\end{array}$} & 35 & $25^{\circ} 06^{\prime} 37^{\prime \prime}$ & $50^{\circ} 03^{\prime} 04^{\prime \prime}$ & $\begin{array}{r}\text { CPS (soybean, } \\
\text { pasture and eucalyptus) }\end{array}$ & 2006 & Atlantic Forest \\
\hline & 36 & $25^{\circ} 06^{\prime} 32^{\prime \prime}$ & $50^{\circ} 03^{\prime} 26^{\prime \prime}$ & $\begin{array}{r}\text { CPS (soy in summer } \\
\text { and oats in winter) }\end{array}$ & 2010 & Atlantic Forest \\
\hline & 37 & $25^{\circ} 06^{\prime} 43^{\prime \prime}$ & $50^{\circ} 03^{\prime} 49^{\prime \prime}$ & Forest & - & Atlantic Forest \\
\hline & 38 & $25^{\circ} 06^{\prime} 54^{\prime \prime}$ & $50^{\circ} 03^{\prime} 49^{\prime \prime}$ & Pasture & - & Atlantic Forest \\
\hline \multirow[t]{4}{*}{$\begin{array}{l}\text { Arroio dos Ratos (AR) - } \\
\text { south }\end{array}$} & 39 & $30^{\circ} 06^{\prime} 14^{\prime \prime}$ & $51^{\circ} 41^{\prime} 32^{\prime \prime}$ & $\begin{array}{l}\text { CPS (soy in summer and } \\
\text { L. multiflorum in winter) }\end{array}$ & 2002 & Pampa \\
\hline & 40 & $30^{\circ} 06^{\prime} 12^{\prime \prime}$ & $51^{\circ} 41^{\prime} 33^{\prime \prime}$ & $\begin{array}{r}\text { CPS (corn or soy in summer } \\
\text { and } L . \text { multiflorum in the winter) }\end{array}$ & 2002 & Pampa \\
\hline & 41 & $30^{\circ} 06^{\prime} 06^{\prime \prime}$ & $51^{\circ} 41^{\prime} 58^{\prime \prime}$ & Campos & - & Pampa \\
\hline & 42 & $30^{\circ} 06^{\prime} 06^{\prime \prime}$ & $51^{\circ} 41^{\prime} 31^{\prime \prime}$ & Pasture & - & Pampa \\
\hline \multirow[t]{4}{*}{$\begin{array}{l}\text { Tuparecetã (TU) - } \\
\text { south }\end{array}$} & 43 & $28^{\circ} 56^{\prime} 34^{\prime \prime}$ & $54^{\circ} 21^{\prime} 35^{\prime \prime}$ & $\begin{array}{l}\text { CPS (soy in summer and } \\
\text { L. multiflorum in winter) }\end{array}$ & 2001 & Pampa \\
\hline & 44 & $28^{\circ} 56^{\prime} 11^{\prime \prime}$ & $54^{\circ} 21^{\prime} 25^{\prime \prime}$ & $\begin{array}{l}\text { CPS (soy in summer and } \\
\text { L. multiflorum in winter) }\end{array}$ & 2001 & Pampa \\
\hline & 45 & $28^{\circ} 56^{\prime} 31^{\prime \prime}$ & $54^{\circ} 20^{\prime} 02^{\prime \prime}$ & Pasture & - & Pampa \\
\hline & 46 & $28^{\circ} 55^{\prime} 48^{\prime \prime}$ & $54^{\circ} 20^{\prime} 29^{\prime \prime}$ & Campos & - & Pampa \\
\hline
\end{tabular}


Table 1. Continued.

\begin{tabular}{|c|c|c|c|c|c|c|}
\hline \multirow[t]{3}{*}{$\begin{array}{l}\text { Nova Esperança do Sul (NS) - } \\
\text { south }\end{array}$} & 47 & $29^{\circ} 27^{\prime} 12^{\prime \prime}$ & $54^{\circ} 48^{\prime} 40^{\prime \prime}$ & $\begin{array}{r}\text { CPS (sorghum, } \\
\text { pasture and eucalyptus) }\end{array}$ & 2007 & Atlantic Forest \\
\hline & 48 & $29^{\circ} 27^{\prime} 33^{\prime \prime}$ & $54^{\circ} 49^{\prime} 17^{\prime \prime}$ & Pasture & - & Atlantic Forest \\
\hline & 49 & $29^{\circ} 27^{\prime} 31^{\prime \prime}$ & $54^{\circ} 49^{\prime} 18^{\prime \prime}$ & Forest & - & Atlantic Forest \\
\hline \multirow[t]{4}{*}{$\begin{array}{l}\text { Bagé }(\mathrm{BA})- \\
\text { south }\end{array}$} & 50 & $31^{\circ} 22^{\prime} 11^{\prime \prime}$ & $54^{\circ} 00^{\prime} 11^{\prime \prime}$ & $\begin{array}{l}\text { CPS (rice in summer and } \\
\text { L. multiflorum in winter) }\end{array}$ & 2007 & Pampa \\
\hline & 51 & $31^{\circ} 22^{\prime} 01^{\prime \prime}$ & $54^{\circ} 00^{\prime} 28^{\prime \prime}$ & Campos & - & Pampa \\
\hline & 52 & $31^{\circ} 28^{\prime} 30^{\prime \prime}$ & $53^{\circ} 58^{\prime} 15^{\prime \prime}$ & $\begin{array}{r}\text { CPS (sorghum, } \\
\text { pasture and eucalyptus) }\end{array}$ & 2005 & Pampa \\
\hline & 53 & $31^{\circ} 19^{\prime} 17^{\prime \prime}$ & $54^{\circ} 00^{\prime} 12^{\prime \prime}$ & $\begin{array}{l}\text { CPS (soy in summer and } \\
\text { L. multiflorum in winter) }\end{array}$ & 2007 & Pampa \\
\hline \multirow{3}{*}{$\begin{array}{l}\text { Capão do Leão (CL) - } \\
\text { south }\end{array}$} & 54 & $31^{\circ} 49^{\prime} 57^{\prime \prime}$ & $52^{\circ} 28^{\circ} 28^{\prime \prime}$ & Campos & - & Pampa \\
\hline & 55 & $31^{\circ} 49^{\prime} 19^{\prime \prime}$ & $52^{\circ} 28^{\prime} 40^{\prime \prime}$ & $\begin{array}{l}\text { CPS (soy in summer and } \\
\text { L. multiflorum in winter) }\end{array}$ & 2007 & Pampa \\
\hline & 56 & $31^{\circ} 49^{\prime} 19^{\prime \prime}$ & $52^{\circ} 28^{\prime} 11^{\prime \prime}$ & $\begin{array}{l}\text { CPS (soy or rice in summer } \\
\text { and L. multiflorum in winter) }\end{array}$ & 2007 & Pampa \\
\hline \multirow[t]{3}{*}{$\begin{array}{l}\text { Passo Fundo }(\mathrm{PF})- \\
\text { south }\end{array}$} & 57 & $28^{\circ} 13^{\prime} 32^{\prime \prime}$ & $52^{\circ} 24^{\prime} 30^{\prime \prime}$ & $\begin{array}{r}\text { CPS (soy or corn in summer } \\
\text { and L. multiflorum or oats in the winter) }\end{array}$ & 1996 & Atlantic Forest \\
\hline & 58 & $28^{\circ} 13^{\prime} 31^{\prime \prime}$ & $52^{\circ} 24^{\prime} 28^{\prime \prime}$ & $\begin{array}{r}\text { CPS (soy or corn in summer } \\
\text { and L. multiflorum or oats in winter) }\end{array}$ & 1996 & Atlantic Forest \\
\hline & 59 & $28^{\circ} 13^{\prime} 30^{\prime \prime}$ & $52^{\circ} 24^{\prime} 24^{\prime \prime}$ & Forest & - & Atlantic Forest \\
\hline
\end{tabular}

approximately $500 \mathrm{~g}$ of soil was collected for chemical analysis. Bulk soil density was determined by using a metal ring (core) pressed into the soil and then determining the weight after drying. Due to the high number of sampling sites and interval depths, only one soil sample for bulk density was collected by soil depth. In order to access the soil bulk density data, see Assad et al. (2013).

Air-dried soil samples were separated from plant material and then homogenized. The samples were then run through sieves for chemical and physical analysis $(2.0 \mathrm{~mm}$ sieve diameter) and analysis of soil carbon $(0.15 \mathrm{~mm}$ sieve diameter). The concentration of soil nitrogen and carbon, which may also include fine charcoal, was determined by using the elemental analyzer at the Laboratory of Isotopic Ecology Center for Nuclear Energy in Agriculture, University of São Paulo (CENA-USP) in Piracicaba, Brazil. Phosphorus concentration was determined by extracting soil phosphorus using the Mehlich-3 method of extraction (Mehlich, 1984), and phosphorus concentration was quantified by the colorimetric blue method. Accordingly, the $\mathrm{C}: \mathrm{P}$ and $\mathrm{N}: \mathrm{P}$ ratios shown here did not use organic phosphorus $\left(\mathrm{P}_{\mathrm{O}}\right)$ concentration as usual (e.g., Walker and Adams, 1958; McGill and Cole, 1981; Stewart and Tiessen, 1987) or total phosphorus $\left(\mathrm{P}_{\mathrm{T}}\right)$ like used by Cleveland and Liptzin (2007) and Tian et al. (2010) but instead Mehlich phosphorus concentration $\left(\mathrm{P}_{\mathrm{ME}}\right)$, which is a mixture of inorganic and organic phosphorus fractions that are, at least theoretically, more available to plants (Gatiboni et al., 2005). As this is less common, because most papers present $C: P_{O}$ or $C: P_{T}$ ratios, the use of $\mathrm{P}_{\mathrm{ME}}$ makes comparison with results obtained elsewhere dif- ficult; this fact constrains the use of $\mathrm{C}: \mathrm{P}_{\mathrm{ME}}$ or $\mathrm{N}: \mathrm{P}_{\mathrm{ME}}$ ratios that are only useful for an intercomparison between our study sites. On the other hand, the use of such ratios could induce a more widespread use of them, since $\mathrm{P}_{\mathrm{ME}}$ determination is much less laborious than the determination of $\mathrm{P}_{\mathrm{O}}$ by the sequential extraction proposed by Hedley et al. (1982).

\subsection{Soil nitrogen and phosphorus stocks}

Carbon stocks were reported in Assad et al. (2013). In this paper, besides carbon concentrations, nitrogen stocks expressed in $\mathrm{Mgha}^{-1}$ and phosphorus stocks expressed in $\mathrm{kg} \mathrm{ha}^{-1}$ were calculated for the soil depth intervals $0-10$, $0-30$, and $0-60 \mathrm{~cm}$ for the paired sites and $0-10$, and 0 $30 \mathrm{~cm}$ for the pasture regional survey by sum stocks obtained in each sampling intervals $(0-5,5-10,10-20,20-30,30$ $40,40-60 \mathrm{~cm})$. Soil nitrogen and phosphorus stocks were estimated based on a fixed mass in order to correct differences caused by land-use changes in soil density (Wendt and Hauser, 2013) using the methodology proposed by Ellert et al. (2008); for details of this correction see Assad et al. (2013).

The cumulative soil nitrogen and phosphorus stocks for fixed depths were calculated by the following equation:

$S=[X] \cdot \rho \cdot z$,

where $S$ is the cumulative soil nitrogen or phosphorus stock for fixed depths in the soil mass $<2 \mathrm{~mm}$ in grams per gram of soil, $[X]$ is the soil nitrogen or phosphorus concentration at the designated depth $(z)$, and $\rho$ is the bulk soil density. For the paired sites, changes in nutrient stocks between current 
land use and native vegetation were obtained by comparing differences between the two stocks. The absolute difference $\left(\Delta \mathrm{N}_{\mathrm{abs}}\right.$ or $\left.\Delta \mathrm{P}_{\mathrm{abs}}\right)$ was expressed in $\mathrm{Mg} \mathrm{ha}^{-1}$ for nitrogen or $\mathrm{kg} \mathrm{ha}^{-1}$ for phosphorus and the relative difference compared to the native vegetation was expressed in percent $\left(\Delta \mathrm{N}_{\text {rel }}\right.$ or $\left.\Delta \mathrm{P}_{\text {rel }}\right)$.

\subsection{Statistical analysis}

In order to test for differences in element concentrations and their respective ratios, we grouped element contents by land use (forest, pasture, CPS) and soil depth $(0-5,5-10,10-20$, 20-30, 30-40, 40-60 cm). Carbon, nitrogen and phosphorus concentration, and soil nitrogen and phosphorus stocks must be transformed using Box-Cox techniques because they did not follow a normal distribution. Accordingly, statistical tests were performed using transformed values, but non-transformed values were used to report average values. The element ratio was expressed as molar ratios, and ratios followed a normal distribution and were not transformed.

For the paired sites, differences between land uses (native vegetation, CPS and pasture) were tested with ANCOVA, with the dependent variables being transformed nutrient concentrations at the soil depth intervals described above, and stocks at the soil layers of $0-10,0-30$, and $0-60 \mathrm{~cm}$; the independent variables were land-use type. As mean annual temperature (MAT), mean annual precipitation (MAP), and soil texture may influence soil nutrient concentration, ratios, and stocks, these variables were also included in the model as co-variables. The post hoc Tukey honest significant test for unequal variance was used to test for differences among nutrient stocks of different land uses. In order to determine whether changes in soil nutrient stocks between current land use and native vegetation were statistically significant, we used a one-sample $t$ test, where the null hypothesis was that the population mean was equal to zero. All tests were reported as significant at a level of $10 \%$. Statistical tests were performed using a STATISTICA 12 package.

\section{Results}

\subsection{Paired study sites}

\subsubsection{Soil carbon, nitrogen, and phosphorus concentrations and related ratios}

Carbon, nitrogen, and phosphorus concentrations decreased with soil depth (Fig. 2). The average carbon concentration was higher in the topsoil $(0-5$ and $5-10 \mathrm{~cm})$ of native vegetation soils compared with pasture and CPS soils $(p=0.05)$. However, in deeper soil layers, there was no statistically significant difference between native vegetation, pasture and CPS soils (Fig. 2a). The average soil nitrogen concentration followed the same pattern as carbon (Fig. 2b). However, differences between forest, pasture and CPS soils were signif-
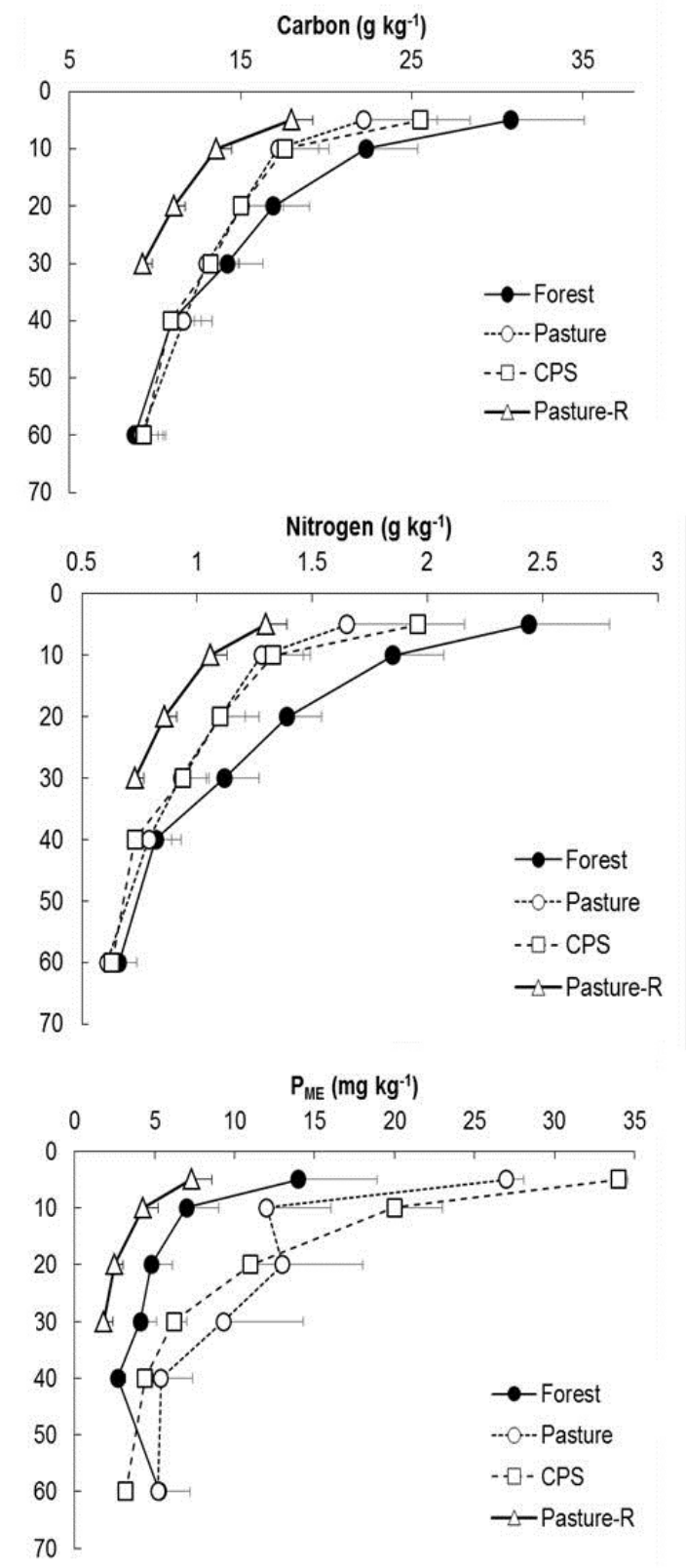

Figure 2. Soil depth variability of (a) carbon, (b) nitrogen and (c) Mehlic-3 extracted phosphorus $\left(\mathrm{P}_{\mathrm{ME}}\right)$ in forest, pasture and CPS soils of the paired study sites and of the regional pasture survey (Pasture-R). Points represent the means by soil depth and the horizontal bars are standard errors.

icant down to the $10-20 \mathrm{~cm}$ soil layer. The $\mathrm{P}_{\mathrm{ME}}$ concentrations in the soil profiles showed a different pattern than carbon and nitrogen. $\mathrm{P}_{\mathrm{ME}}$ concentrations were higher in the CPS and pasture soils than in forest soils in the topsoil and also in the soil depth layer of 10-20 cm (Fig. 2c).

The $\mathrm{C}: \mathrm{N}$ ratios of pasture and CPS soils were higher than the native vegetation soils in all soil depths; however, this difference was not statistically significant for any particular 

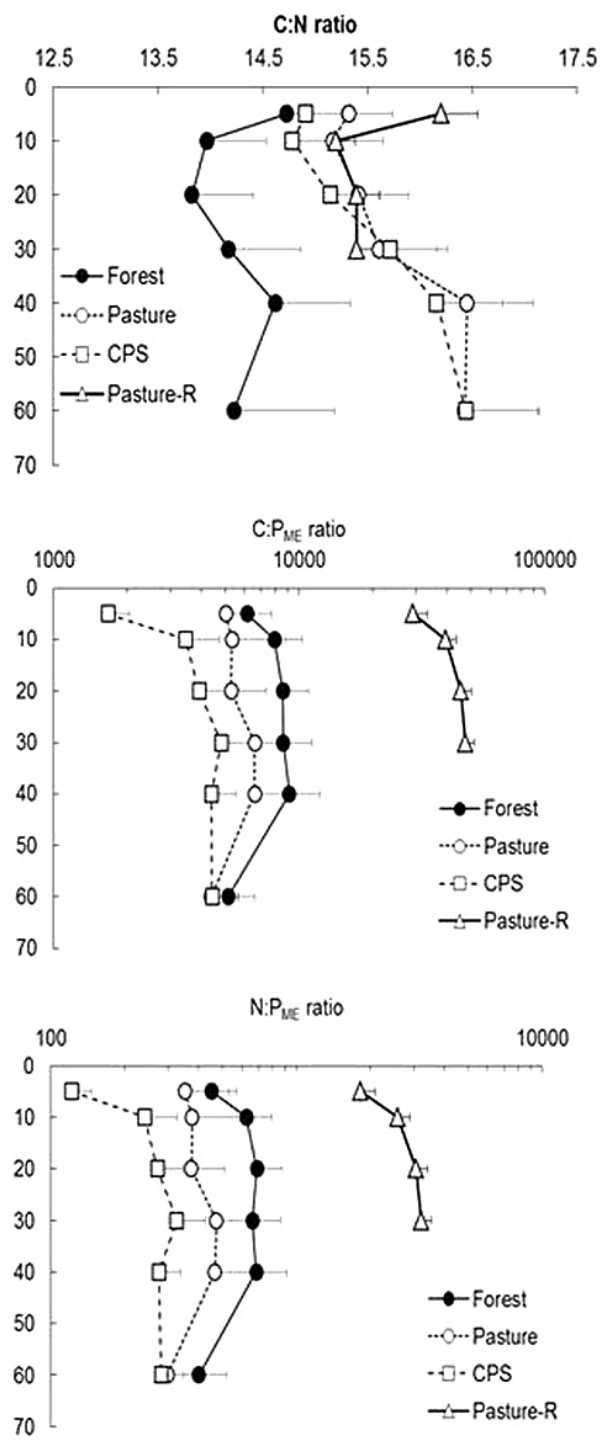

Figure 3. Soil depth variability of (a) $C: N$ ratios, (b) $C: P_{M E}$ and (c) $\mathrm{N}: \mathrm{P}_{\mathrm{ME}}$ in forest, pasture and CPS soils of the paired study sites and of the regional pasture survey (Pasture-R). Points represent the means by soil depth and the horizontal bars are standard errors.

depth (Fig. 3a). There was a difference in the $\mathrm{C}: \mathrm{P}_{\mathrm{ME}}$ ratio between forest, pasture and CPS soils; this ratio was higher in the forest soils, intermediate in the pasture, and lower in the CPS soils (Fig. 3b). Due to the wide variability of the data, differences were only significant in the first three soil depth intervals: $0-5 \mathrm{~cm}(p<0.01), 5-10 \mathrm{~cm}(p<0.01)$, and $10-20 \mathrm{~cm}(p=0.03)$. Finally, the $\mathrm{N}: \mathrm{P}_{\mathrm{ME}}$ showed a similar trend to $\mathrm{C}: \mathrm{P}_{\mathrm{ME}}$, with higher ratios in native vegetation soils, decreasing in the pasture and reaching the lowest values in the CPS soils (Fig. 3c). Again, values were only different at the same soil depth intervals observed for $\mathrm{C}: \mathrm{P}_{\mathrm{ME}}$, with all of them at a probability ratio lower than 0.01 .

\subsubsection{Soil nitrogen and phosphorus stocks}

The average nitrogen stock of the native vegetation soils in the topsoil was $2.27 \mathrm{Mg} \mathrm{ha}^{-1}$ decreasing significantly to $1.72 \mathrm{Mg} \mathrm{ha}^{-1}$ in the CPS $(p=0.05)$ and to $1.54 \mathrm{Mg} \mathrm{ha}^{-1}$ in pasture soils $(p<0.01$; Table 2$)$. In the next soil layer $(0-30 \mathrm{~cm})$, the same tendency was observed. The average nitrogen stock was equal to $5.12 \mathrm{Mgha}^{-1}$, decreasing significantly to $3.94 \mathrm{Mg} \mathrm{ha}^{-1}$ in the CPS $(p=0.04)$ and to $3.84 \mathrm{Mg} \mathrm{ha}^{-1}$ in pasture soils $(p=0.03$; Table 2$)$. On the other hand, differences in soil nitrogen stocks among different land uses were not significant at the $0-60 \mathrm{~cm}$ of the soil layer; the nitrogen soil stock was $7.30 \mathrm{Mg} \mathrm{ha}^{-1}$ in the native vegetation and 5.93 and $6.16 \mathrm{Mg} \mathrm{ha}^{-1}$ in the CPS and pasture soils, respectively (Table 2). In general, there was a net loss of nitrogen stocks between native vegetation and current land uses in the soil (Table 2). In the forest-CPS pairs for the topsoil, $\Delta \mathrm{N}_{\mathrm{abs}}=-0.64 \mathrm{Mg} \mathrm{ha}^{-1}$ and $\Delta \mathrm{N}_{\text {rel }}=-22 \%$, both differences were significant at the $1 \%$ level (Table 2). The same pattern was observed for the $0-30 \mathrm{~cm}$ soil interval, where $\Delta \mathrm{N}_{\mathrm{abs}}=-1.28 \mathrm{Mg} \mathrm{ha}^{-1}$ and $\Delta \mathrm{N}_{\text {rel }}=-20 \%$ (Table 2). In the forest-pasture paired sites, the $\Delta \mathrm{N}_{\mathrm{abs}}\left(-0.63 \mathrm{Mgha}^{-1}\right)$ and $\Delta \mathrm{N}_{\text {rel }}(-28 \%)$ found in the topsoil were both statistically significant at $1 \%$ (Table 2). The same was true for the $0-30 \mathrm{~cm}$ soil layer, where $\Delta \mathrm{N}_{\mathrm{abs}}=-1.10 \mathrm{Mg} \mathrm{ha}^{-1}$ was equivalent to a loss of $-22 \%$ (Table 2 ).

On the other hand, a net gain of phosphorus was observed between native vegetation and current land uses in the soil. The phosphorus soil stock in the topsoil of native vegetation areas was equal to $11.27 \mathrm{~kg} \mathrm{ha}^{-1}$, increasing significantly to $30.06 \mathrm{~kg} \mathrm{ha}^{-1}(p<0.01)$ in the CPS soil and to $21.6 \mathrm{~kg} \mathrm{ha}^{-1}(p<0.01)$ in the pasture soils (Table 3). Considering the $0-30 \mathrm{~cm}$ soil layer, the phosphorus stock in the native vegetation soils was $21.74 \mathrm{~kg} \mathrm{ha}^{-1}$, also significantly increasing in the CPS soils to $49.50 \mathrm{~kg} \mathrm{ha}^{-1}(p=0.02)$, and to $47.60 \mathrm{~kg} \mathrm{ha}^{-1}$ in the pasture soils (Table 3). Finally, in the $0-60 \mathrm{~cm}$ soil layer, the phosphorus stock in the native vegetation soils was $42.70 \mathrm{~kg} \mathrm{ha}^{-1}$, which was not significantly lower than the phosphorus soil stock in the CPS soils, which was equal to $62.90 \mathrm{~kg} \mathrm{ha}^{-1}$. On the other hand, the soil phosphorus stock in the pasture soils was $68.33 \mathrm{~kg} \mathrm{ha}^{-1}$, which is significantly different $(p=0.02)$ than the soil phosphorus stock of the native vegetation soils (Table 3 ). In relative terms, in the topsoil, for the native vegetationCPS paired sites, an overall phosphorus gain was observed: $\Delta \mathrm{P}_{\mathrm{abs}}=20.56 \mathrm{~kg} \mathrm{ha}^{-1}$ and $\Delta \mathrm{P}_{\text {rel }}=325 \%$, both significant at the $1 \%$ level (Table 3 ). The same pattern was observed at the $0-30 \mathrm{~cm}$ soil layer, where $\Delta \mathrm{P}_{\mathrm{abs}}=27.03 \mathrm{~kg} \mathrm{ha}^{-1}$ and $\Delta \mathrm{P}_{\text {rel }}=205 \%$, and at the $0-60 \mathrm{~cm}$ soil layer, where $\Delta \mathrm{P}_{\mathrm{abs}}=25.64 \mathrm{~kg} \mathrm{ha}^{-1}$ and $\Delta \mathrm{P}_{\text {rel }}=145 \%$ (Table 3). In the native vegetation-pasture paired sites, the same increase in phosphorus stocks was also observed in the pasture soils. In the topsoil, $\Delta \mathrm{P}_{\mathrm{abs}}=10.06 \mathrm{~kg} \mathrm{ha}^{-1}(p<0.01)$ and $\Delta \mathrm{P}_{\text {rel }}=52 \%(p<0.01)$ were statistically significant (Table 3). The same was true for the $0-30 \mathrm{~cm}$ soil 
Table 2. Mean, standard deviation (SD), and minimum and maximum of soil nitrogen stocks $\left(\mathrm{N}_{\text {stock}}\right.$, expressed as $\left.\mathrm{Mg}^{-1}\right)$ at $0-10,0-30$, and $0-60 \mathrm{~cm}$ soil depth layer for forest, crop-livestock systems and pasture soils at the paired study sites. $\Delta \mathrm{N}_{\text {abs }}$ is the difference between the soil nitrogen stock of native vegetation and crop livestock systems and pasture soils obtained in the paired study sites (expressed as $\left.\mathrm{Mg} \mathrm{ha}^{-1}\right) . \Delta \mathrm{N}_{\text {rel }}$ is the same difference expressed as a percentage. Nitrogen losses are indicated by a minus sign $(-)$.

\begin{tabular}{|c|c|c|c|c|c|}
\hline & \multicolumn{5}{|c|}{ Native vegetation $(0-10 \mathrm{~cm})$} \\
\hline & $\mathrm{N}$ & Mean & SD & Minimum & Maximum \\
\hline \multirow[t]{3}{*}{$\mathrm{N}_{\text {stock }}$} & 16 & 2.27 & 1.04 & 0.97 & 4.64 \\
\hline & \multicolumn{5}{|c|}{ CPS $(0-10 \mathrm{~cm})$} \\
\hline & $\mathrm{N}$ & Mean & SD & Minimum & Maximum \\
\hline $\mathrm{N}_{\text {stock }}$ & 27 & 1.72 & 0.72 & 0.52 & 2.80 \\
\hline$\Delta \mathrm{N}_{\mathrm{abs}}$ & 27 & -0.64 & 0.76 & -2.54 & 0.52 \\
\hline \multirow[t]{3}{*}{$\Delta \mathrm{N}_{\mathrm{rel}}$} & 27 & -21.81 & 30.63 & -71.37 & 42.93 \\
\hline & \multicolumn{5}{|c|}{ Pasture $(0-10 \mathrm{~cm})$} \\
\hline & $\mathrm{N}$ & Mean & SD & Minimum & Maximum \\
\hline $\mathrm{N}_{\text {stock }}$ & 13 & 1.54 & 0.89 & 0.55 & 2.82 \\
\hline$\Delta \mathrm{N}_{\mathrm{abs}}$ & 13 & -0.63 & 0.70 & -2.02 & 0.43 \\
\hline \multirow[t]{3}{*}{$\Delta \mathrm{N}_{\mathrm{rel}}$} & 13 & -27.89 & 27.53 & -70.77 & 18.71 \\
\hline & \multicolumn{5}{|c|}{ Native vegetation $(0-30 \mathrm{~cm})$} \\
\hline & $\mathrm{N}$ & Mean & $\mathrm{SD}$ & Minimum & Maximum \\
\hline \multirow[t]{3}{*}{$\mathrm{N}_{\text {stock }}$} & 16 & 5.12 & 2.12 & 2.20 & 9.01 \\
\hline & \multicolumn{5}{|c|}{ CPS $(0-30 \mathrm{~cm})$} \\
\hline & $\mathrm{N}$ & Mean & SD & Minimum & Maximum \\
\hline $\mathrm{N}_{\text {stock }}$ & 27 & 3.94 & 1.65 & 1.45 & 7.65 \\
\hline$\Delta \mathrm{N}_{\mathrm{abs}}$ & 27 & -1.28 & 1.70 & -4.89 & 1.60 \\
\hline \multirow[t]{3}{*}{$\Delta \mathrm{N}_{\text {rel }}$} & 27 & -19.81 & 29.19 & -65.14 & 45.81 \\
\hline & \multicolumn{5}{|c|}{ Pasture $(0-30 \mathrm{~cm})$} \\
\hline & $\mathrm{N}$ & Mean & SD & Minimum & Maximum \\
\hline $\mathrm{N}_{\text {stock }}$ & 13 & 3.84 & 1.85 & 1.52 & 6.49 \\
\hline$\Delta \mathrm{N}_{\mathrm{abs}}$ & 13 & -1.10 & 1.14 & -3.20 & 0.80 \\
\hline \multirow[t]{3}{*}{$\Delta \mathrm{N}_{\mathrm{rel}}$} & 13 & -21.84 & 18.95 & -63.63 & 14.06 \\
\hline & \multicolumn{5}{|c|}{ Native vegetation $(0-60 \mathrm{~cm})$} \\
\hline & $\mathrm{N}$ & Mean & $\mathrm{SD}$ & Minimum & Maximum \\
\hline \multirow[t]{3}{*}{$\mathrm{N}_{\text {stoc }}$} & 16 & 7.30 & 3.28 & 2.68 & 12.00 \\
\hline & \multicolumn{5}{|c|}{ CPS $(0-60 \mathrm{~cm})$} \\
\hline & $\mathrm{N}$ & Mean & SD & Minimum & Maximum \\
\hline $\mathrm{N}_{\text {stock }}$ & 27 & 5.93 & 2.51 & 2.12 & 11.68 \\
\hline$\Delta \mathrm{N}_{\mathrm{abs}}$ & 27 & -1.48 & 2.37 & -5.12 & 2.82 \\
\hline \multirow[t]{3}{*}{$\Delta \mathrm{N}_{\mathrm{rel}}$} & 27 & -13.41 & 31.47 & -59.97 & 41.42 \\
\hline & \multicolumn{5}{|c|}{ Pasture $(0-60 \mathrm{~cm})$} \\
\hline & $\mathrm{N}$ & Mean & SD & Minimum & Maximum \\
\hline $\mathrm{N}_{\text {stock }}$ & 13 & 6.16 & 2.79 & 2.80 & 10.19 \\
\hline$\Delta \mathrm{N}_{\mathrm{abs}}$ & 13 & -1.54 & 1.47 & -3.89 & 1.05 \\
\hline$\Delta \mathrm{N}_{\text {rel }}$ & 13 & -17.67 & 20.20 & -47.21 & 20.62 \\
\hline
\end{tabular}


layer - in this case $\Delta \mathrm{P}_{\mathrm{abs}}=25.70 \mathrm{~kg} \mathrm{ha}^{-1}(p<0.01)$ and $\Delta \mathrm{P}_{\text {rel }}=220 \%(p<0.01)-$ and for the $0-60 \mathrm{~cm}$ soil layer, where $\Delta \mathrm{P}_{\mathrm{abs}}=25.42 \mathrm{~kg} \mathrm{ha}^{-1}(p<0.01)$ and $\Delta \mathrm{P}_{\text {rel }}=172 \%$ ( $p<0.01$; Table 3$)$.

\subsection{Regional survey of pasture soils}

\subsubsection{Soil carbon, nitrogen, and phosphorus concentrations and related ratios}

We compared element concentrations and ratios of the regional survey pasture soils with the native vegetation soil site of the plot-level paired sites (Figs. 2 and 3). Carbon, nitrogen and phosphorus concentrations decreased with soil depth, and were significantly lower $(p<0.01)$ in the pasture soils than in the native vegetation soils (Fig. 2). The $\mathrm{C}: \mathrm{N}$ ratio of the regional pasture survey was higher than the native vegetation soil (Fig. 3). The $\mathrm{C}: \mathrm{P}_{\mathrm{ME}}$ and $\mathrm{N}: \mathrm{P}_{\mathrm{ME}}$ ratios were much higher in the pasture soils of the regional survey compared with forest soils, and in these cases there was a sharp increase with soil depth (Fig. 3).

\subsubsection{Soil nitrogen and phosphorus stocks}

At the $0-10 \mathrm{~cm}$ soil layer the average total soil nitrogen stock was equal to $1.66 \pm 0.87 \mathrm{Mg} \mathrm{ha}^{-1}$ (Table 4), and at $0-30 \mathrm{~cm}$ the average soil stock was $3.91 \pm 1.90 \mathrm{Mg} \mathrm{ha}^{-1}$. At the $0-10$ and $0-30 \mathrm{~cm}$ soil layers, the average phosphorus stock was 8.50 and $14.71 \mathrm{~kg} \mathrm{ha}^{-1}$, respectively (Table 4). The average nitrogen stock in the pasture soils of the regional survey at both depth layers $(0-10 \mathrm{~cm}$ and $0-30 \mathrm{~cm})$ was very similar to the stocks found in the pasture and CPS of the paired-site survey, and therefore also lower than the soil stocks found in the native vegetation areas (Table 4). On the other hand, the average phosphorus stock in the pasture soils of the regional survey was much lower than the soil stocks of pasture and CPS of the paired-site surveys, which are even smaller than the soil stocks of native vegetation areas (Table 4).

\section{Discussion}

\subsection{Sources of uncertainty}

Due to time and financial constraints, we were unable to sample soil from native vegetation near each pasture site in the regional survey. This poses a challenge because it is important to compare changes in the soil nitrogen and phosphorus stocks with the native vegetation as done in the paired study sites. In order to overcome the lack of original nutrient soil stocks, we used estimates of native vegetation obtained in the paired sites. Another difficulty was the lack of reliable information on the land-use history; we cannot guarantee that differences among land uses already existed or were due to the replacement of the native vegetation (Braz et al., 2012; Assad et al., 2013). In addition, we only have a point-in-time

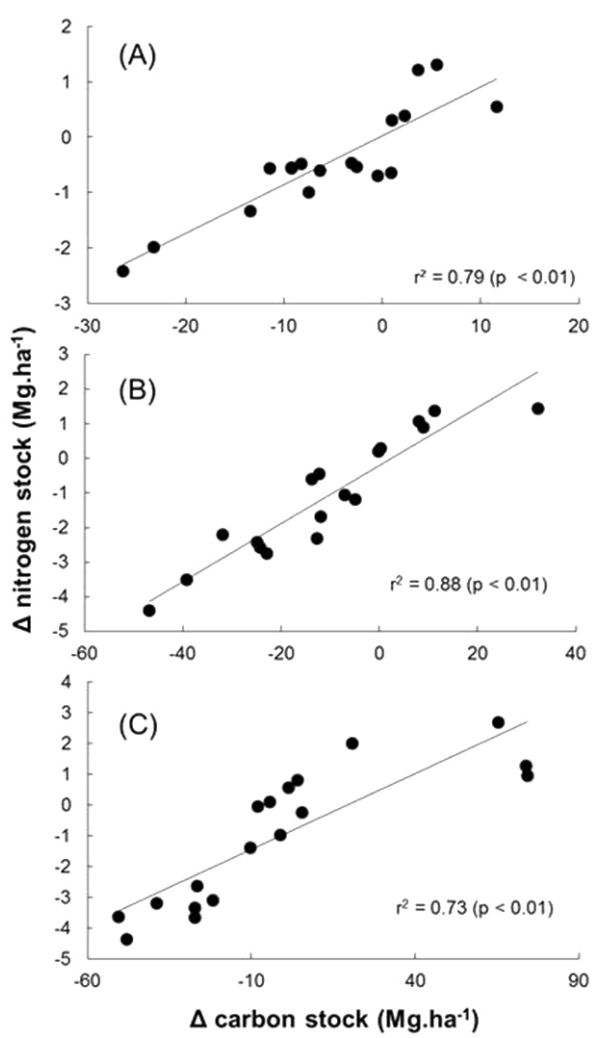

Figure 4. Scatter plot of soil carbon stock losses (data from Assad et al., 2013), and soil nitrogen stock losses found in this study between CPS and native vegetation in the paired study sites (a) $0-10 \mathrm{~cm}$, (b) $0-30 \mathrm{~cm}$ and (c) $0-60 \mathrm{~cm}$ depth intervals.

measurement; we did not follow temporal changes in nitrogen and phosphorus soil stocks. Therefore, it is not possible to know whether the soil organic matter achieved a new steady-state equilibrium; as a consequence our results should be interpreted with caution (Sanderman and Baldock, 2010).

\section{2 $\mathrm{C}: \mathrm{N}: \mathbf{P}_{\mathrm{ME}}$ soil stoichiometry}

Overall, the $\mathrm{C}: \mathrm{N}$ ratio was lower in the native vegetation soils compared with pasture and CPS soils (Fig. 3a). These differences are probably explained by a nitrogen loss and not a carbon gain, since soil carbon stocks in pasture and CPS soils were lower than in native vegetation soils (Assad et al., 2013). Lower soil $\mathrm{C}: \mathrm{N}$ ratios as observed in the native vegetation could influence nitrogen dynamics, favoring faster organic matter decomposition and nitrogen mineralization by microorganisms in these soils (Mooshammer et al., 2014b). However, it is difficult to conclude whether a small difference between native vegetation soils and the others would be enough to alter the balance between mineralization and immobilization, especially because Mooshammer et al. (2014a) showed that microbial nitrogen use efficiency has a large variability in mineral soils. 
Table 3. Mean, standard deviation (SD), and minimum and maximum of soil phosphorus stocks $\left(\mathrm{P}_{\text {stock }}\right.$, expressed as kg ha $\left.{ }^{-1}\right)$ at $0-10,0-30$, and $0-60 \mathrm{~cm}$ soil depth layer for forest, crop-livestock systems and pasture soils at the paired study sites. $\Delta \mathrm{P}_{\text {abs }}$ is the difference between the soil phosphorus stock of native vegetation and crop livestock systems and pasture soils obtained in the paired study sites (expressed as $\left.\mathrm{kg} \mathrm{ha}^{-1}\right) . \Delta \mathrm{P}_{\text {rel }}$ is the same difference expressed as a percentage. Phosphorus losses are indicated by a minus sign $(-)$.

\begin{tabular}{|c|c|c|c|c|c|}
\hline & \multicolumn{5}{|c|}{ Native vegetation $(0-10 \mathrm{~cm})$} \\
\hline & $\mathrm{N}$ & Mean & SD & Minimum & Maximum \\
\hline \multirow[t]{3}{*}{$\mathrm{P}_{\text {stock }}$} & 16 & 11.27 & 14.26 & 0.80 & 60.50 \\
\hline & \multicolumn{5}{|c|}{ CPS $(0-10 \mathrm{~cm})$} \\
\hline & $\mathrm{N}$ & Mean & SD & Minimum & Maximum \\
\hline $\mathrm{P}_{\text {stock }}$ & 27 & 30.06 & 25.63 & 1.60 & 95.50 \\
\hline$\Delta \mathrm{P}_{\mathrm{abs}}$ & 27 & 20.56 & 23.91 & -14.50 & 78.50 \\
\hline \multirow[t]{3}{*}{$\Delta \mathrm{P}_{\text {rel }}$} & 27 & 324.96 & 381.11 & -23.97 & 1650.11 \\
\hline & \multicolumn{5}{|c|}{ Pasture $(0-10 \mathrm{~cm})$} \\
\hline & $\mathrm{N}$ & Mean & SD & Minimum & Maximum \\
\hline$P_{\text {stock }}$ & 13 & 21.63 & 22.35 & 0.60 & 78.10 \\
\hline$\Delta \mathrm{P}_{\mathrm{abs}}$ & 13 & 10.06 & 26.78 & -50.50 & 62.05 \\
\hline \multirow[t]{3}{*}{$\Delta \mathrm{P}_{\mathrm{rel}}$} & 13 & 52.14 & 813.43 & -83.47 & 2818.72 \\
\hline & \multicolumn{5}{|c|}{ Native vegetation $(0-30 \mathrm{~cm})$} \\
\hline & $\mathrm{N}$ & Mean & SD & Minimum & Maximum \\
\hline \multirow[t]{3}{*}{$\mathrm{P}_{\text {stock }}$} & 16 & 21.74 & 24.49 & 3.10 & 105.50 \\
\hline & \multicolumn{5}{|c|}{ CPS $(0-30 \mathrm{~cm})$} \\
\hline & $\mathrm{N}$ & Mean & SD & Minimum & Maximum \\
\hline$P_{\text {stock }}$ & 27 & 49.50 & 37.11 & 3.20 & 137.50 \\
\hline$\Delta \mathrm{P}_{\mathrm{abs}}$ & 27 & 27.03 & 41.48 & -79.01 & 102.50 \\
\hline \multirow[t]{3}{*}{$\Delta \mathrm{P}_{\text {rel }}$} & 27 & 205.05 & 245.34 & -74.18 & 900.08 \\
\hline & \multicolumn{5}{|c|}{ Pasture $(0-30 \mathrm{~cm})$} \\
\hline & $\mathrm{N}$ & Mean & SD & Minimum & Maximum \\
\hline$P_{\text {stock }}$ & 13 & 47.60 & 60.77 & 2.30 & 218.00 \\
\hline$\Delta \mathrm{P}_{\mathrm{abs}}$ & 13 & 25.70 & 64.17 & -83.51 & 191.35 \\
\hline \multirow[t]{3}{*}{$\Delta \mathrm{P}_{\mathrm{rel}}$} & 13 & 218.59 & 324.31 & -79.16 & 937.76 \\
\hline & \multicolumn{5}{|c|}{ Native vegetation $(0-60 \mathrm{~cm})$} \\
\hline & $\mathrm{N}$ & Mean & SD & Minimum & Maximum \\
\hline \multirow[t]{3}{*}{$P_{\text {stock }}$} & 16 & 42.70 & 53.92 & 6.40 & 216.50 \\
\hline & \multicolumn{5}{|c|}{ CPS $(0-60 \mathrm{~cm})$} \\
\hline & $\mathrm{N}$ & Mean & SD & Minimum & Maximum \\
\hline $\mathrm{P}_{\text {stock }}$ & 27 & 62.90 & 39.75 & 6.90 & 155.49 \\
\hline$\Delta \mathrm{P}_{\mathrm{abs}}$ & 27 & 25.64 & 62.51 & -175.00 & 107.49 \\
\hline \multirow[t]{3}{*}{$\Delta \mathrm{P}_{\text {rel }}$} & 27 & 145.54 & 178.00 & -100.00 & 535.23 \\
\hline & \multicolumn{5}{|c|}{ Pasture $(0-60 \mathrm{~cm})$} \\
\hline & $\mathrm{N}$ & Mean & SD & Minimum & Maximum \\
\hline $\mathrm{P}_{\text {stock }}$ & 13 & 68.33 & 72.12 & 11.90 & 241.40 \\
\hline$\Delta \mathrm{P}_{\mathrm{abs}}$ & 13 & 25.42 & 89.37 & -184.52 & 201.16 \\
\hline$\Delta \mathrm{P}_{\text {rel }}$ & 13 & 171.92 & 285.12 & -100.00 & 850.26 \\
\hline
\end{tabular}


Table 4. Statistics of soil nitrogen $\left(\mathrm{N}_{\text {stocks }}\right.$, express as $\left.\mathrm{Mgha}^{-1}\right)$ and phosphorus $\left(\mathrm{P}_{\text {stocks }}, \mathrm{kg} \mathrm{ha}^{-1}\right)$ at $0-10$ and $0-30 \mathrm{~cm}$ soil depth layers for pasture soils included in the regional survey.

\begin{tabular}{lrrrrrrr}
\hline & Depth $(\mathrm{cm})$ & $\mathrm{N}$ & Mean & SD & Median & Minimum & Maximum \\
\hline $\mathrm{N}_{\text {stocks }}$ & 10 & 115 & 1.66 & 0.87 & 1.49 & 0.40 & 4.20 \\
$\mathrm{~N}_{\text {stocks }}$ & 30 & 115 & 3.91 & 1.90 & 3.61 & 1.01 & 8.90 \\
$\mathrm{P}_{\text {stocks }}$ & 10 & 115 & 8.50 & 14.60 & 3.08 & 0.50 & 89.50 \\
$\mathrm{P}_{\text {stocks }}$ & 30 & 115 & 14.71 & 26.90 & 5.72 & 1.01 & 179.50 \\
\hline
\end{tabular}

Another important trend was the lower depth variability of $\mathrm{C}: \mathrm{N}$ ratios compared with the depth variability of carbon and nitrogen concentrations (Fig. 2a and b). This trend is consistent with the initial hypothesis of Tian et al. (2010), who hypothesized that the $\mathrm{C}: \mathrm{N}$ ratio would not vary widely with depth because of the coupling of carbon and nitrogen in the soil. According to Tischer et al. (2014), such constancy is a consequence of similar inputs of organic matter by primary producers to the soils and also due to the fact that $\mathrm{N}$ transformations (immobilization or mineralization) are coupled to $\mathrm{C}$ transformations, especially when soil organic carbon molecules are converted into $\mathrm{CO}_{2}$ by heterotroph microbial soil population (McGill et al., 1975; McGill and Cole, 1981).

Among different land uses, the elements: $\mathrm{P}_{\mathrm{ME}}$ were also distinct (Fig. 3b and c). As the carbon concentration and stock were lower in pasture and CPS soils compared to native vegetation soils (Assad et al., 2013), it is likely that the $\mathrm{C}: \mathrm{P}_{\mathrm{ME}}$ is lower in the pasture soils and in the CPS soils due to a combination of $\mathrm{C}$ loss with an increase in $\mathrm{P}_{\mathrm{ME}}$ caused by the use of $P$ fertilizers (Fig. 2c). The same trend was observed with $\mathrm{N}: \mathrm{P}_{\mathrm{ME}}$, and a combination of $\mathrm{N}$ loss couple with $\mathrm{C}$ loss and $\mathrm{P}_{\mathrm{ME}}$ enrichment in pasture and CPS soils compared with native vegetation soils. The $C: P_{M E}$ and $N: P_{M E}$ increased with depth particularly between 5 and $10 \mathrm{~cm}$ depth; after that depth, ratios were approximately constant, decreasing between 40 and $60 \mathrm{~cm}$ (Fig. $3 \mathrm{~b}$ and c). One reason for this decrease in the deepest soil layer could be the contribution of inorganic P through weathering (Tian et al., 2010), as attested to by an increase in $\mathrm{P}_{\mathrm{ME}}$ in the deepest soil layer in soils under native vegetation (Fig. 2c).

\subsection{Land-use changes alter nitrogen and phosphorus stocks}

In most of the plot-level paired sites and in most of the regional soil survey, we found a loss of nitrogen compared to the native vegetation. It seems that this is a common pattern observed for different crops and different types of land management in several regions of Brazil, like in the northeast (Lima et al., 2011; Fracetto et al., 2012; Barros et al., 2013; Sacramento et al., 2013), in central Brazil (Cardoso et al., 2010; Silva et al., 2011; Guareschi et al., 2012) and in the south (Sisti et al., 2004; Sá et al., 2013; Santana et al.,
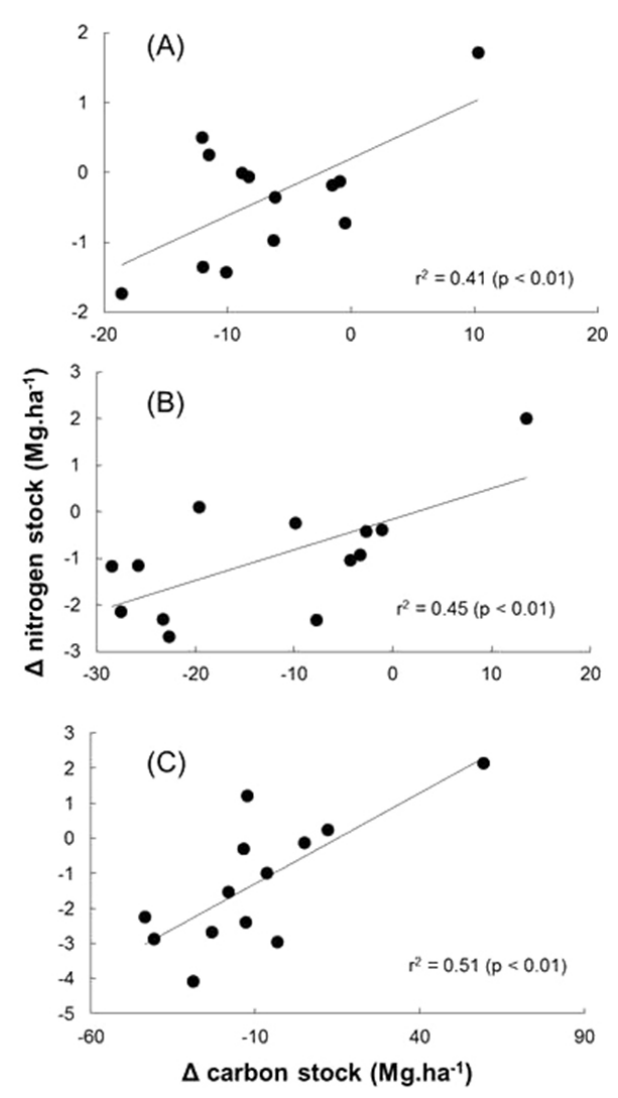

Figure 5. Scatter plot of soil carbon stock losses (data from Assad et al., 2013), and soil nitrogen stock losses found in our study between pasture and native vegetation in the paired study sites (a) $0-10 \mathrm{~cm}$, (b) $0-30 \mathrm{~cm}$ and (c) $0-60 \mathrm{~cm}$ depth intervals.

2013). Sá et al. (2013) found lower soil nitrogen stocks in several farms located in southern Brazil (Paraná State) that have adopted no-till and crop rotation systems for at least 10 years compared with the native vegetation of the region. On the other hand, the adoption of no-till systems tends to increase soil nitrogen stocks compared to conventional tillage (Sisti et al., 2004; Sá et al., 2013). In this respect, it is interesting to note that the only three sites (SL, PG, AP) where the soil nitrogen stocks were higher in the agriculture field than in the native vegetation were CPS sites, where no-till was practiced and there was a system of crop rotation, with 


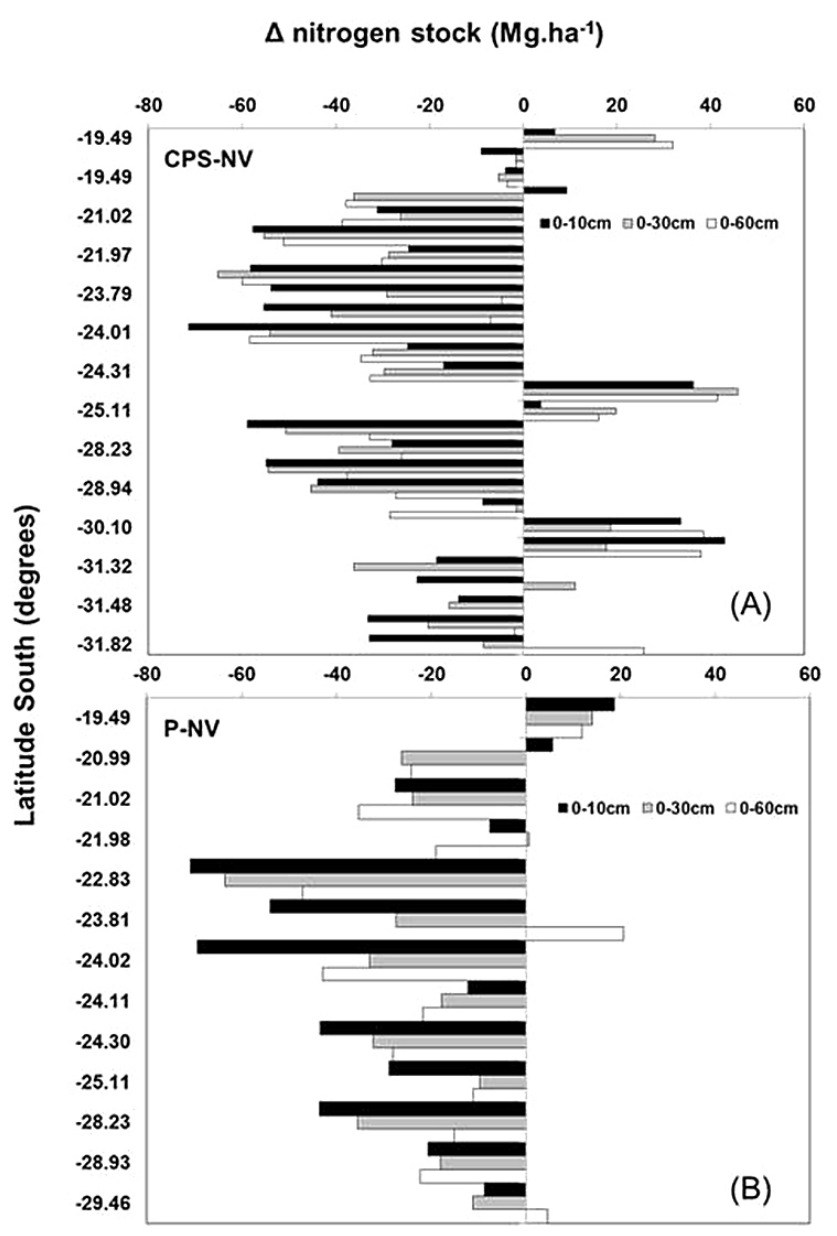

Figure 6. Absolute difference of soil nitrogen stocks between different depth intervals: (a) crop-livestock systems (CPS) and native vegetation (NV) and (b) pasture $(P)$ and native vegetation $(\mathrm{NV})$ at different paired study sites. Each paired-site study area is indicated by its latitude. Losses are indicated by a minus sign (-).

soybean in the summer and oat or wheat in the winter (Table 1).

Nitrogen dynamics are regulated by a balance between inputs, losses and transformations between different forms of nitrogen (Drinkwater et al., 2000). Regarding nitrogen inputs, the main natural nitrogen input is via biological nitrogen fixation (BNF), and the main anthropogenic addition is via N-mineral fertilizer inputs (Vitousek et al., 2002). In crops like soybean, BNF is also important as a source of new nitrogen to the system, especially in Brazil, where soybean may fix higher amounts of nitrogen (Alves et al., 2003). Several of the CPSs evaluated in this study involve the use of soybean under crop rotation systems (Table 1); however, decreases in soil nitrogen stocks of these CPSs were also observed in these systems (Fig. 6a and b). The same was observed by Boddey et al. (2010) comparing soil carbon and nitrogen stocks of no-till and conventional tillage systems involving a crop rotation with soybean in farms located in Rio

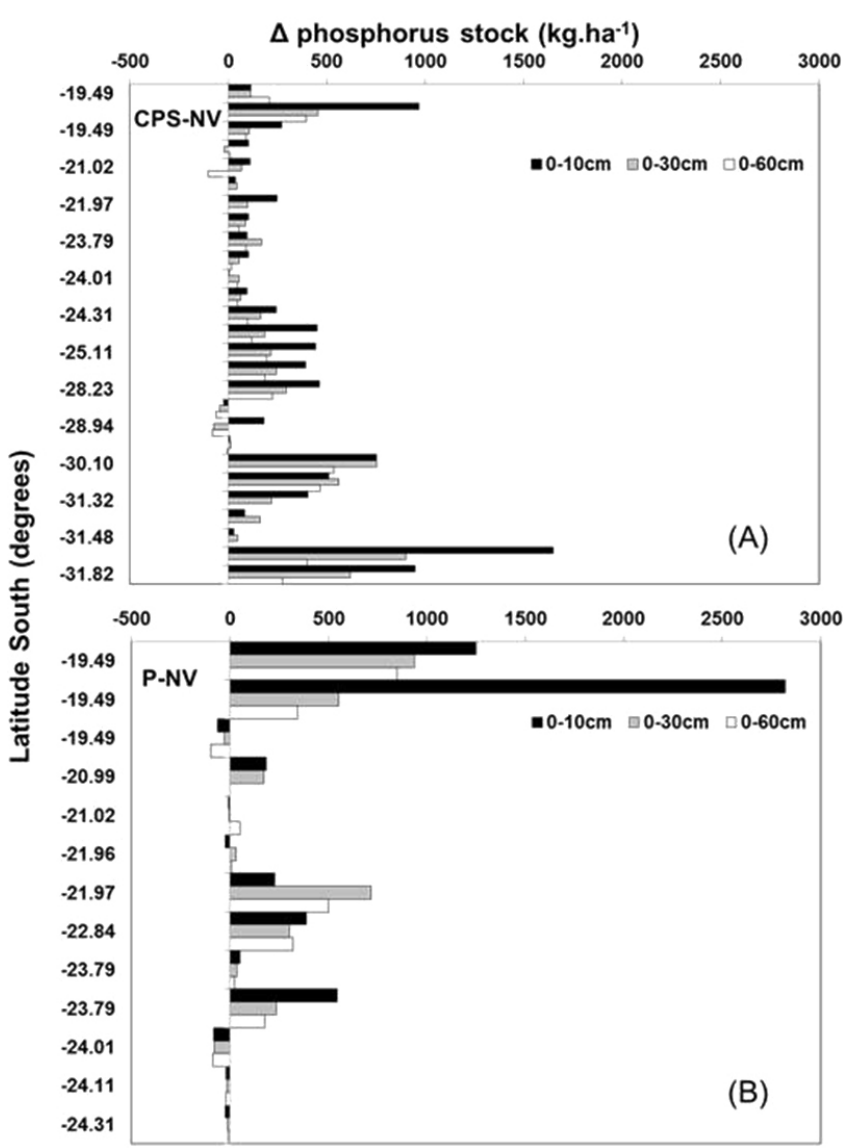

Figure 7. Absolute difference of soil phosphorus stocks between different depth intervals: (a) crop-livestock systems (CPS) and native vegetation $(\mathrm{NV})$ and $(\mathbf{b})$ pasture $(P)$ and native vegetation $(\mathrm{NV})$ at different paired study sites. Each paired-site study area is indicated by its latitude. Losses are indicated by a minus sign (-).

Grande do Sul State (southern Brazil). According to these authors, the nitrogen export by grain harvesting is high enough to prevent a buildup of this nutrient in the soil (Boddey et al., 2010).

On the other hand, most pastures in Brazil are not fertilized, so over time a decrease in nitrogen inputs coupled with an increase in nitrogen outputs is generally observed, leading to lower mineralization and nitrification rates (Verchot et al., 1999; Melillo et al., 2002 Garcia-Montiel et al., 2000; Wick al., 2005; Neill et al., 2005; Carmo et al., 2012). According to Boddey et al. (2004), not even the return of nitrogen to soil pasture via urine and dung is sufficient to compensate for other nitrogen losses. As a consequence, the continuous use of unfertilized pastures leads to overall $\mathrm{N}$ impoverishment in the system, leading to lower soil nitrogen stocks, as observed in this study.

We found a positive and significant $(p<0.01)$ correlation between soil carbon stock losses found by Assad et al. (2013) and the soil nitrogen stock losses found in this study. Such correlations were especially significant in the CPSs, where 
more than $70 \%$ of the variance in the nitrogen losses was explained by carbon losses (Figs. 4 and 5). These correlations are an indication that whatever mechanisms are leading to such losses are simultaneously affecting carbon and nitrogen (McGill et al., 1975). There are several studies at the plot level showing that changes in soil properties is one of the leading causes affecting losses of organic matter with soil cultivation (e.g., Mikhailova et al., 2000; Kucharik et al., 2001). In addition, findings of several regional and global surveys also pointed in the same direction (e.g., Davidson and Ackerman, 1993; Amundson 2001; Guo and Gifford, 2002; Zinn et al., 2005; Ogle et al., 2005; Don et al., 2011; Eclesia et al., 2012). It seems that a combination of decreasing organic matter inputs, in cases where crops replaced native forests, with an increase in soil organic matter decomposition leads to a decrease in the long run. This decrease seems to be especially fostered in annual crops by exposing bare soil between harvests, leading to higher temperatures (Baker et al., 2007; Coutinho et al., 2010; Salimon et al., 2004), which in turn leads to higher decomposition rates (e.g., Davidson and Janssens, 2006; Dorrepaal et al., 2009). For instance, Carmo et al. (2012) found higher soil temperature and high $\mathrm{CO}_{2}$ emissions in pasture soil compared with the forest soil nearby, with both sites located in the southeast region of Brazil (São Paulo State).

On the other hand, we observed a general increase in soil phosphorus stocks of pasture and CPS paired sites compared with soil stocks of the native vegetation (Fig. 7a and b). The higher soil phosphorus stocks in the CPS could be explained by the addition of phosphorus fertilizer to the fields (Aguiar et al. 2013; Messiga et al., 2013; Costa et al., 2014). Generally, an increase in soil phosphorus is observed after use of $\mathrm{P}$ fertilizers in the topsoil due to the low mobility of phosphorus, especially in no-till systems (Costa et al., 2007; Pavinatto et al., 2009; Messiga et al., 2010). In several of the CPS sites, there are crop rotations of maize, rice and soybean, and all these crops are fertilized with phosphorus, especially soybean, because phosphorus is an important nutrient in the biological nitrogen fixation process (Divito and Sadras, 2014). The variation in phosphorus concentration with soil depth provides indirect support for this hypothesis. In the majority of the CPS sites and even pasture soils of the paired sites, there is a gradient in phosphorus concentration, with much higher concentrations near the soil surface (Fig. 2c).

The soil phosphorus stocks of pastures located in the paired sites were higher than soil phosphorus stocks of the regional pasture survey. For instance, in the $0-10 \mathrm{~cm}$ soil layer, the average $\mathrm{P}_{\text {stock }}$ of pasture soil at the paired sites was equal to $22 \mathrm{~kg} \mathrm{ha}^{-1}$ (Table 3), which is significantly higher than the average $\mathrm{P}_{\text {stock }}$ of pasture soil sampled in the regionallevel survey $\left(9 \mathrm{~kg} \mathrm{ha}^{-1}\right.$, Table 4). This latter average is similar to the average $P_{\text {stock }}$ of the native vegetation sampled in the paired study sites, which was equal to $12 \mathrm{~kg} \mathrm{ha}^{-1}$ (Table 3). As we mentioned earlier, we do not have accurate information on pasture management and grazing conditions.
However, as the pasture paired sites were located in research stations and well-managed farms, we believe that, overall, the pasture in these areas is in better condition compared with pasture included in the regional survey. As already mentioned, in some pasture of the paired sites, a steep decrease in phosphorus content with soil depth was observed, which is indirect evidence that these pastures received some kind of phosphorus amendment or lime application that raised the $\mathrm{pH}$ and made phosphorus available to plants (Uehara and Gillman, 1981). If this is the case, these differences in pasture management will probably explain differences observed in soil phosphorus stocks between pastures of the paired sites and regional survey. This is because Fonte et al. (2014) found that soils of well-managed pastures located on poor tropical soils had great differences in soil aggregation, which in turn influence the soil phosphorus level, favoring a higher phosphorus content in well-managed pastures compared to degraded pastures. On the other hand, Garcia-Montiel et al. (2000) and Hamer et al. (2013) found an increase in soil phosphorus stocks for several years after the conversion of Amazonian forests to unfertilized pastures. The main cause of this increase seems to be soil fertilization promoted by ash of forest fires, coupled with root decomposition of the original vegetation. However, it seems that there is a decrease in available phosphorus with pasture aging, mainly in strongly weathered tropical soils (Townsend et al., 2002; Numata et al., 2007).

In an earlier paper, Assad et al. (2013) showed a decrease in soil carbon stock in relation to the original vegetation either for pasture and CPS soils. In this paper we found that nitrogen stocks also decrease considerably with land-use changes, even in well-managed CPSs, and especially in pastures of the regional survey that reflect better the reality of pasture management in Brazil. These findings have important policy implications because Brazil recently implemented a program (Low Carbon Agriculture) devoted to increasing carbon and nitrogen concentration in soils through a series of techniques, especially no-till, CPSs, and improvement of degraded pastures. Therefore, the findings of this paper set a baseline of soil nutrients stocks and stoichiometry for future comparisons.

Acknowledgements. We would like to thank the British Embassy for financial support. Jim Hesson of academicenglishsolutions.com revised the English.

Edited by: S. Fontaine

\section{References}

Aguiar, A. C. F., Cândido, C. S. C., Carvalho, C. S., Monroe, P. H. M., and Moura, E. G.: Organic matter fraction and pools of phosphorus as indicators of the impact of land use in the Amazonian periphery, Ecol. Indic., 30, 158-164, 2013. 
Allison, S. D., Wallenstein, M. D., and Bradford, M. a.: Soil-carbon response to warming dependent on microbial physiology, Nat. Geosci., 3, 336-340, doi:10.1038/ngeo846, 2010.

Alves, B. J. R., Boddey, R. M., and Urquiaga, S.: The success of BNF in soybean in Brazil, Plant Soil, 252, 1-9, 2003.

Amundson, R.: The Carbon Budget in Soils, Annu. Rev. Earth Planet. Sci., 29, 535-562, 2001.

Assad, E. D., Pinto, H. S., Martins, S. C., Groppo, J. D., Salgado, P. R., Evangelista, B., Vasconcellos, E., Sano, E. E., Pavão, E., Luna, R., Camargo, P. B., and Martinelli, L. A.: Changes in soil carbon stocks in Brazil due to land use: paired site comparisons and a regional pasture soil survey, Biogeosciences, 10, 61416160, doi:10.5194/bg-10-6141-2013, 2013.

Baker, J. M., Ochsner T. E., Ventera, R. T., and Giffis, T. J.: Tillage and soil carbon sequestration: What do we really know?, Agr. Ecosys. Environ., 118, 1-5, 2007.

Ball-Coelho, B. Salcedo, I. H. Tiessen, H., and Stewart, W. B.: Short- and long-term phosphorus dynamics in fertilized ultisol under sugarcane. Soil Sci. Soc. Am., 57, 1027-1034, 1993.

Barros, J. D. S., Chaves, L. H. G., Chaves, I. B., Farias, C. H. A., and Pereira, W. E.: Estoque de carbono e nitrogênio em sistemas de manejo do solo, nos tabuleiros costeiros paraibanos, Revista Caatinga, Mossoró, 26, 35-42, 2013.

Bayer, C., Martin-Neto, L., Mielniczuk, J., Pavinato, A., and Dieckow, J.: Carbon Sequestration in Two Brazilian Cerrado Soils Under No-till, Soil Till. Res., 86, 237-245, 2006.

Boddey, R. M., Macedo, R., Tarré, R.M, Ferreira, E., Oliveira O. C., Rezende, C. P., Cantarutti, R. B., Pereira J. M., Alves, B. J. R., and Urquiaga, S.: Nitrogen cycling in Brachiaria pastures: the key to understanding the process of pasture decline. Agr. Ecosys. Environ., 103, 389-403, 2004.

Boddey, R. M., Jantalia, C. P., Conceição, P. C., Zanata, J. A., Cimélio, B., Mielniczuk, J., Dieckow, J., Santos, H. P., Denardins, J. E., Aita, C., Giacomini, S. J., Alves, B. J. R., and Urquiaga, S.: Carbon accumulation at depth in Ferralsols under zero-till subtropical agriculture, Glob. Change Biol., 16, 784795, 2010.

Braz, S. P., Urquiaga, S., Alves, B. J. R., Jantalia, C. P., Guimarães, A. P., dos Santos, C. A., dos Santos, S. C., Pinheiro, E. F. M., and Boddey, R. M.: Soil Carbon Stocks under Productive and Degraded Brachiaria Pastures in the Brazilian Cerrado, Soil Sci. Soc. Am., 77, 914-928, 2012.

Bustamante, M. M. C., Nobre, C. A., Smeraldi, R., Aguiar, A. P. D., Barioni, L. G., Ferreira, L. G., Longo, K., May, P.,Pinto, A. S., and Ometto, J. P. H. B.: Estimating greenhouse gas emissions fom cattle raising in Brasil, Clim. Change, 115, 559-577, 2012.

Cardoso, E. L., Silva, M. L. N., Silva, C. A., Curi, N., and Freitas, D.A.F.: Estoques de carbono e nitrogênio em solo sob florestas nativas e pastagens no bioma Pantanal, Pesquisa Agropecuária Brasileira, 45, 1028-1035, 2010.

Carmo, J. B., Sousa Neto, E. R., Duarte-Neto, P. J., Ometto, J. P. H. B, and Martinelli, L. A.: Conversion of the coastal Atlantic forest to pasture: Consequences for the nitrogen cycle and soil greenhouse gas emissions. Agr. Ecosys. Environ., 148, 37-43, 2012.

Cerri, C. E. P., Piccolo, M. C., Feigl, B. J., Paustian, K., Cerri, C. C., Victoria, R. L., and Melillo, J. M.: Interrelationships among soil total $\mathrm{C}$ and $\mathrm{N}$, microbial biomass, trace gas fluxes, and internal $\mathrm{N}$-cycling in soil under pasture of the Amazon region, J. Sust. Agr., 25, 45-69, 2006.
Cleveland, C. C. and Liptzin, D.: C:N : P stoichiometry in soil: is there a "Redfield ratio" for the microbial biomass?, Biogeochemistry, 85, 235-252, doi:10.1007/s10533-007-9132-0, 2007.

Costa, M. H., Yanagi, S. N. M., Souza, P. J. O. P., Ribeiro, A., and Rocha, E. J. P.: Climate change in Amazonia caused by soybean cropland expansion, as compared to caused by pastureland expansion., Geophys. Res. Lett., 34, L07706, doi:10.1029/2007GL029271, 2007.

Costa, S. E. V. G. A., Souza, E. D., Anghinoni, I., Carvalho, P. C. F., Martins, A. P., Kunrath, T. R., Cecagno, D., and Balerini, F.: Impact of an integrated no-till crop-livestock system on phosphorus distribution, availability and stock, Agr. Ecosys. Environ., 190, 43-51, 2014.

Coutinho, R. P., Urquiaga S., Boddey, R. M., Alves, B. J. R., Torres, A. Q. A., and Jantalia, C. P.: Estoque de carbono e nitrogênio e emissão de $\mathrm{N}_{2} \mathrm{O}$ em diferentes usos do solo na Mata Atlântica, Pesquisa Agropecuária Brasileira, Brasília, 45, 195-203, 2010.

Davidson, E. A. and Ackerman, I. L.: Changes in soil carbon inventories following cultivation of previously untilled soils, Biogeochemistry, 20, 161-193, 1993.

Davidson, E. A. and Janssens, I.A.: Temperature sensitivity of soil carbon decomposition and feedbacks to climate change, Nature, 440, 165-173, 2006.

Davidson, E. A., Keller, M., Erickson, H. E., Verchot, L. V., and Veldkamp, E.: Testing a conceptual model of soil emissions of nitrous and nitric oxides. BioScience, 50, 667-680, 2000.

Ding, F., Hu, Y.-L., Li, L.-J., Li, A., Shi, S., Lian, P.-Y., and Zeng, D.-H.: Changes in soil organic carbon and total nitrogen stocks after conversion of meadow to cropland in Northeast China, Plant Soil, 373, 659-672, doi:10.1007/s11104-013-1827-5, 2013.

Divito, G. A. and Sadras, V. O.: How do phosphorus, potassium and sulphur affect plant growth and biological nitrogen fixation in crop and pasture legumes? A meta-analysis, Field Crops Res., 156, 161-171, 2014.

Don, A., Schumacher, J., and Freibauer, A.: Impact of Tropical Land-use Change on Soil Organic Carbon Stocks - a Metaanalysis, Glob. Change Biol., 17, 1658-1670, 2011.

Dorrepaal, E., Toet, S., Van Logtestijn, R. S. P., Swart, E., Van De Weg, M. J., Callaghan, T. V., and Aerts, R.: Carbon Respiration from Subsurface Peat Accelerated by Climate Warming in the Subarctic, Nature, 460, 616-619, 2009.

Drinkwater, L. E., Janke, R. R., and Rossoni-Longnecker, L.: Effects of tillage intensity on nitrogen dynamics and productivity in legume-based grain systems, Plant Soil, 227, 99-113, 2000.

Eclesia, R. P., Jobbagy, E. G., Jackson, R. B., Biganzoli, F., and Piñeiro, G.: Shifts in soil organic carbon for plantation and pasture establishment in native forests and grasslands of South America, Glob. Change Biol., 18, 3237-3251, 2012.

Ellert, B. H., Janzen, H. H., Van den Bygaart, A. J., and Bremer, E.: Measuring change in soil organic carbon storage, in: Soil Sampling and Methods of Analysis, Chapter 3, edited by: Carter, M. R. and Gregorich, E. G., CRC Press, Boca Raton, USA, 25-38, 2008.

Erickson, H., Keller, M., and Davidson, E.A.: Nitrogen Oxide Fluxes and Nitrogen Cycling during Post-agricultural Succession and Forest Fertilization in the Humid Tropics, Ecosystems, 4, 67-84, 2001.

Fonte, S. J., Nesper, M., Hegglin, D., Velásquez, J. E., Ramirez, B., Rao, I. M., Bernasconi, S. M., Bünemann, E. K., Frossard, E., 
and Oberson, A.: Pasture degradation impacts soil phosphorus storage via changes to aggregate-associated soil organic matter in highly weathered tropical soils, Soil Biol. Biochem., 68, 150157, 2014.

Fracetto, F. J. C., Fracetto, G. G. M., Cerri, C. C., Feigl, B. J., and Siqueira Neto, M.: Estoques de carbono e nitrogênio no solo cultivado com mamona na caatinga, Revista Brasileira de Ciência do Solo, 36, 1545-1552, 2012.

Gama-Rodrigues, A. C., Sales, M. V. S., Silva, P. S. D., Comerford, N. B. Cropper, W. P., and Gama-Rodrigues, E. F: An exploratory analysis of phosphorus transformations in tropical soils using structural equation modeling, Biogeochemistry, 118, 453469,2014

Garcia-Montiel, D. C., Neill, C, Melillo, J., Thomas, S., Steudler, P. A., and Cerri, C. C.: Soil Phosphorus Transformations Following Forest Clearing for Pasture in the Brazilian Amazon, Soil Sci. Soc. Ame. J., 64, 1792-1804, 2000.

Gatiboni, L. C., Kaminski, J., and Santos, D. R.: Modificações nas formas de fósforo do solo após extrações sucessivas com Mehlich-1, Mehlich-3 e resina trocadora de ânions, Revista Brasileira de Ciência do Solo, 29, 363-371, 2005.

Godfray, H. C. J., Beddington, J. R., Crute, I. R., Haddad, L., Lawrence, D., Muir, J. F., Pretty, J., Robinson, S., Thomas, S. M., and Toulmin, C.: Food security: The challenge of feeding 9 billion people, Science, 327, 812-818, 2010.

Guareschi, R. F., Pereira, M. G., and Perin, A.: Deposição de resíduos vegetais, matéria orgânica leve, estoques de carbono e nitrogênio e fósforo remanescente sob diferentes sistemas de manejo no cerrado Goiano, Revista Brasileira de Ciência do Solo, 36, 909-920, 2012.

Guo, L. B. and Gifford, R. M.: Soil Carbon Stocks and Land Use Change: a Meta Analysis, Glob. Change Biol., 8, 345-360, 2002.

Hamer, U., Potthast, K., Burneo, J. I., and Makeschin, F.: Nutrient stocks and phosphorus fractions in mountain soils of Southern Ecuador after conversion of forest to pasture, Biogeochemistry, 112, 495-510, 2013.

Hättenschwiler, S., Coq, S., Barantal, S., and Handa, I. T.: Leaf traits and decomposition in tropical 5 rainforests: revisiting some commonly held views and towards a new hypothesis, New Phytol., 189, 950-965, doi:10.1111/j.1469-8137.2010.03483.x, 2011.

Hedley, M. J., Stewart, J. W. B., and Chauhan, B. S.: Changes in inorganic and organic soil phosphorus fractions induced by cultivation practices and by laboratory incubations, Soil Sci. Soc. Am. J., 46, 970-976, 1982.

Hessen, D. O., Ågren, G. I., Anderson, T. R., Elser, J. J., Peter, C., Hessen, D. A. G. O., Agren, G. I., Anderson, T. R., Elser, J. J., and Ruiter, P. C. D. E.: Carbon Sequestration in Ecosystems?: The Role of Stoichiometry carbon sequestration in ecosystems?: the role of stoichiometry, Ecology, 85, 1179-1192, 2004.

Jiao, F., Wen, Z.-M., An, S.-S., and Yuan, Z.: Successional changes in soil stoichiometry after land abandonment in Loess Plateau, China, col. Eng., 58, 249-254, doi:10.1016/j.ecoleng.2013.06.036, 2013.

Keathing, B. A., Carberry, P. S., Bindraban, P. S., Asseng, S., Meinke, H., and Dixon, J.: Eco-efficient agriculture: concepts, challenges, and opportunities, Crop Science, 50, 109-119, 2010.

Kucharik, C. J., Brye, K. R., Norman, J. M., Foley, J. A., Gower, S. T., and Bundy, L.G.: Measurements and Modeling of Carbon and Nitrogen Cycling in Agroecosystems of Southern Wiscon- sin: Potential for SOC Sequestration during the Next 50 Years, Ecosystems, 4, 237-258, 2001.

Lapola, D. M., Martinelli, L. A., Peres, C. A., Ometto, J. P. H. B., Ferreira, M. E., Nobre, C. A., Aguiar, A. P. D., Bustamante, M. M. C., Cardoso, M. F., Costa, M. H., Joly, C. A., Leite, C. C., Moutinho, P., Sampaio, G., Strassburg, B. B. N., and Vieira, I. C. G.: Pervasive transition of the Brazilian land-use system, Nature Climate Change, 4, 27-35, 2014.

Lima, S. S., Carvalho Leite, L. F., Oliveira, F. C., and Costa, D. B.: Atributos químicos e estoques de carbono e nitrogênio em argissolo vermelho-amarelo sob sistemas agroflorestais e agricultura de corte e queima no norte do Piauí, Revista Árvore, 35, 51-60, 2011.

Machado, L. A. Z., Balbino, L. C., and Ceccon, G.: Integração lavoura-pecuária-floresta - Estruturação dos sistemas de integração lavoura-pecuária, Embrapa Agropecuária Oeste, Dourados-MS, 46 pp., 2011.

Maia, S., Ogle, S., and Cerri, C.: Effect of grassland management on soil carbon sequestration in Rondônia and Mato Grosso states, Brazil, Geoderma, 149, 84-91, 2009.

Marchão, R.L., Becquer T., Brunet, D., Balbino, L. C., Vilela, L., and Brossard, M.: Carbon and nitrogen stocks in a Brazilian clayey Oxisol: 13-year effects of integrated crop-livestock management systems, Soil Till. Res., 103, 442-450, 2009.

Martinelli, L. A., Naylor, R., Vitousek, P. M., and Moutinho, P.: Agriculture in Brazil: impacts, costs, and opportunities for a sustainable future, Environmental Sustainability, 2, 431-438, 2010.

McGill, W. B. and Cole, C. V.: Comparative aspects of cycling of organic C, N, S and P through soil organic matter, Geoderma, 26, 267-286, 1981.

McGill, W. B., Shields, J. A., and Paul, E. A.: Relation between carbon and nitrogen turnover in soil organic fractions of microbial origin, Soil Biol. Biochem. 7, 57-63, 1975.

Mehlic, A.: Mehlich 3 soil test extractant: a modification of Mehlich 2 extractant, Commun. Soil Sci. Plan., 15, 1409-1416, doi:10.1080/00103628409367568, 1984.

Melillo, J. M., Steudler, P. A., Aber, J. D., Newkirk, K., Lux, H., Bowles, F. P., Catricala, C., Magill, A., Ahrens, T., and Morrisseau, S.: Soil warming and carbon-cycle feedbacks to the climate systems, Science, 298, 2173-2176, 2002.

Mello, F. F. C., Cerri, C. E. P., Holbrook, H. M., Paustian, K., Maia, S. M. F., Galdos, M. V., Bernoux, M., and Cerri, C. C.: Payback time for soil carbon and sugar-cane ethanol, Nature Climate Change, 4, 605-609, doi:10.1038/NCLIMATE2239, 2014.

Messiga, A. J., Ziadi, N., Morel, C., and Parent L.E.E.: Soil phosphorus availability in no-till versus conventional tillage following freezing and thawing cycles, Can. J. Soil Sci., 90, 419-428, 2010.

Messiga, A. J., Ziadi, N., Bélanger, G., and Morel, C.: Soil nutrientes and other major properties in grassland fertilized with nitrogen and phosphurus, Soil Sci. Soc. of Am., 18, 643-652, 2013.

Mikhailova, E. A., Bryant, R. B., Vassenev, I. I., Schwager, S. J., and Post, C. J.: Cultivation Effects on Soil Carbon and Nitrogen Contents at Depth in the Russian Chernozem, Soil Sci. Soc. Am. J., 64, 738-745, 2000.

Mooshammer, M., Wanek, W., Hämmerle, I., Fuchslueger, L., Hofhansl, F., Knoltsch, A., Schnecker, J., Takriti, M., Watzka, M., Wild, B., Keiblinger, K. M., Zechmeister-Boltenstern, S., and Richter, A.: Adjustment of microbial nitrogen use efficiency to 
carbon:nitrogen imbalances regulates soil nitrogen cycling, Nat. Commun., 5, 3694, doi:10.1038/ncomms4694, 2014a.

Mooshammer, M., Wanek, W., Zechmeister-Boltenstern, S., and Richter, A.: Stoichiometric imbalances between terrestrial decomposer communities and their resources: mechanisms and implications of microbial adaptations to their resources, Front. Microbiol., 5, 22, doi:10.3389/fmicb.2014.00022, 2014b.

Neill, C., Steudler, P. A., Garcia-Montiel, D. C., Melillo, J. M., Feigl, B. J., Piccolo, M. C., and Cerri, C. C.: Rates and controls of nitrous oxide and nitric oxide emissions following of forest to pasture in Rondônia, Nutr. Cycl. Agroecosys., 71, 1-15, 2005.

Numata, I., Chadwick O. A., Roberts D. A., Schimel J. P., Sampaio F. F., Leonidas F. C., and Soares J. V.: Temporal nutrient variation in soil and vegetation of post-forest pastures as a function of soil order, pasture age, and management, Rondonia, Brazil, Agr. Ecosys. Environ., 118, 159-172, 2007.

Oberson, A, Friesen, D. K., Rao, I.M., Bühler, S., and Frossard, E.: Phosphorus Transformations in an Oxisol under contrasting land-use systems: The role of the soil microbial biomass, Plant Soil, 237, 197-210, 2001.

Ogle, S. M., Breidt F. J., and Paustian, K.: Agricultural management impacts on soil organic carbon storage under moist and dry climatic conditions of temperate and tropical regions, Biogeochemistry, 72, 87-121, 2005.

Pavinato, P. S., Merlin, A., and Rosolem, C. A.: Phosphorus fractions in Brazilian Cerrado soils as affected by tillage, Soil Till. Res., 105, 149-155, 2009.

Sá, J. C. M., Cerri, C. C., Dick, W. A., Lal, R., Venske Filho, S. P., Piccolo, M. P., and Feigl, B. E.: Organic Matter Dynamics and Carbon Sequestration Rates for a Tillage Chronosequence in a Brazilian Oxisol, Soil Sci. Soc. Am. J., 65, 1486-1499, 2001.

Sá, J. C. M., Santos, J. B., Lal, R., Moraes, A., Tivet, F., Sá, M. F. M., Briedis, C., Ferreira, A. O., Eurich, G., Farias, A., and Friedrich, T.: Soil-Specific Inventories of Landscape Carbon and Nitrogen Stocks under No-Till and Native Vegetation to Estimate Carbon Offset in a Subtropical Ecosystem, Soil Sci. Soc. Am. J., 77, 2094-2110, 2013.

Sacramento, J. A. A. S., Araújo, A. C. M., Escobar, M. E. O., Xavier, F. A. S., Cavalcante, A. C. R., and Oliveira, T. S.: Soil carbon and nitrogen stocks in traditional agricultural and agroforestry systems in the semiarid region of Brazil, Revista Brasileira de Ciência do Solo, 37, 784-795, 2013.

Salimon, C. I., Victoria, R. L., Davidson, E. A., and Melo, A. W. F.: $\mathrm{CO}_{2}$ flux from soil in pastures and forests in southwestern Amazonia, Glob. Change Biol., 10, 833-843, 2004.

Sanchez, P. A., Couto, W., and Buol, S. W.: The fertility capability soil classification system: interpretation, applicability and modification, Geoderma, 27, 283-309, 1982.

Sanderman, J. and Baldock, J. A.: Accounting for soil carbon sequestration in national inventories: a soil scientist's perspective, Environ. Res. Lette., 5, 1-6, 2010.

Santana, G. S., Dick, D. P., Tomazi, M., Bayer, C., and Jacquest, V. A.: Chemical Composition and Stocks of Soil Organic Matter in a South Brazilian Oxisol under Pasture, J. Brazil.Chem. Soc., 24, 821-829, 2013.

Schrumpf, M., Kaiser, K., and Schulze, E.-D.: Soil organic carbon and total nitrogen gains in an old growth deciduous forest in Germany, PLoS One, 9, e89364, doi:10.1371/journal.pone.0089364, 2014.
Silva, E. F., Lourente, E. P. R., Marchetti, M. E., Mercante, F. M., Ferreira, A. K. T., and Fujii, G. C.: Frações lábeis e recalcitrantes da matéria orgânica em solos sob integração lavourapecuaria, Pesquisa Agropecuária Brasileira, 46, 1321-1331, 2011.

Sisti, C. P. J., Santos, H. P., Kohhann, R. Alves, B. J. R., Urquiaga, S., and Boddey, R. M.: Change in carbon and nitrogen stocks in soil under 13 years of conventional or zero tillage in southern Brazil, Soil Till. Res., 76, 39-58, 2004.

Stewart, J. W. B. and Tiessen, H.: Dynamics of soil organic phosphorus. Biogeochemistry, 4, 41-60, 1987.

Tian, H., Chen, G., Zhang, C., Melillo, J. M., and Hall, C. S. H.: Pattern and variation of $\mathrm{C}: \mathrm{N}: \mathrm{P}$ ratios in China's soils: a synthesis of observational data, Biogeochemistry, 98, 139-151, 2010.

Tiessen, H. and Stewart, J. W. B.: Particle-size Fractions and their Use in Studies of Soil Organic Matter: II. Cultivation Effects on Organic Matter Composition in Size Fractions, Soil Sci. Soc. Am., 47, 509-514, 1983.

Tiessen, H., Stewart, J. W. B., and Bettany, J. R.: Cultivation effects on the amounts and concentration of carbon, nitrogen, and phosphorus in grassland soils, Agr. J., 74, 831-835, 1982.

Tilman, D., Balzer, C., Hill, J., and Befort, B. L.: Global food demand and the sustainable intensification of agricukture, P. Natl. Acad. Sci., 108, 20260-20264, 2011.

Tischer, A., Potthast, K. ,and Hamer, U.: Land-use and soil depth affect resource and microbial stoichiometry in a tropical mountain rainforest region of southern Ecuador, Oecologia, 175, 375-93, doi:10.1007/s00442-014-2894-x, 2014.

Townsend, A. R., Asner, G. P., Cleveland, C. C., Lefer, M. E., and Bustamante, M. M. C.: Unexpected changes in soil phosphorus dynamics along pasture chronosequences in the humid tropics, J. Geophys. Res., 107, 34, doi:10.1029/2001JD000650, 2002.

Uehara G. and Gillman G. P.: The mineralogy, chemistry, and physics of tropical soils with variable charge clays, Westview Press, Inc.: Boulder, Colorado, 170 pp., 1981.

Verchot, L. V., Davidson, E. A., Cattanio, J. H., Ackerman, I. L., Erickson, W. E., and Keller, M.: Land use change and biogeochemical controls of nitrogen oxide emissions from soils in eastern Amazonia, Global Biochem. Cy. 13, 31-46, 1999.

Vitousek, P. M., Cassman, K., Cleveland, C., Crews, T., Field, C. B., Grimm, N. B., Howarth, R. W., Marino, R., Martinelli, L. A., and Rastetter, E. B.: Sprent, J.I. Towards an ecological understanding of biological N fixation, Biogeochemistry, 57, 1-45, 2002.

Walker, T. W., and Adams, A. F. R.: Studies on soil organic matter. Soil Sci., 85, 307-318, 1958.

Walker, T. W., and Syers, J. K.: The fate of phosphorus during pedogenesis. Geoderma, 15, 1-19, 1976.

Wendt, J. W. and Hauser, S: An equivalent soil mass procedure for monitoring soil organic carbon in multiple soil layers, Eur. J. Soil Sci., 64, 58-65, doi:10.1111/ejss.12002, 2013.

Wick, B., Veldkamp, E., de Mello, W. Z., Keller, M., and Crill, P.: Nitrous oxide fluxes and nitrogen cycling along a pasture chronosequence in Central Amazonia, Brazil, Biogeosciences, 2, 175-187, doi:10.5194/bg-2-175-2005, 2005.

Zinn, Y. L., Lal, R., and Resck, D. V. S.: Changes in Soil Organic Carbon Stocks Under Agriculture in Brazil, Soil Till. Res., 84, 28-40, 2005. 